\title{
DA ORDEM DE VOCAÇÃO HEREDITÁRIA NOS DIREITOS BRASILEIRO E ITALIANO'
}

\author{
Giselda Maria Fernandes, Vovaes Hironaka
}

\begin{abstract}
Resumo:
A autora aborda neste trabalho a coordenação preferencial dos grupos sucessiveis ao sistema dispar de vocação do cônjuge concorrente criado pelo novo Código Civil brasilciro, dependente do estado civil do autor da herança. Aborda, ainda, a sucessão de quem cra casado ou separado de fato, a de pessoa que era unida estavelmente; do viúvo, do solteiro. do divorciado e de separado judicialmente ou do separado de fato.

Palavras-chave: Novo Código Civil. Grupos sucessiveis. Vocação do cônjuge concorrente. Sucessão. Vocação hereditária. ('ódigo Civil italiano.

Abstract:

The author discusses from the preferential coordination of sucessive groups to unmatched spouse's devolution of sucession system created by the new Brazilian Civil Code, arranged in function of the deceased's marital status. Furthermore, she discusses sucession of married, civil union spouscd; widow, single, divorced and legally separated or separated from bed and board persons.
\end{abstract}

Keywords: New Brazilian Civil Code. Sucessive Groups. Spouse's devolution. Devolution of Sucession. Italian Civil Code.

1. A coordenação preferencial dos grupos sucessiveis

Itabaiana de Oliveira, em seu monumental Tratado de Direito das Sucessôes editado em três volumes, define a ordem de vocação hereditária como sendo o estabelecimento, pelo legislador, de uma coordenução prefercncial dos grupos sucessiveis, ${ }^{2}$ na hora de chamá-los a herdar os bens daquele que falece, em virtude do falecimento ter ocorrido $a b$ intestato ou pelo menos sem um testamento que abarcasse a totalidade do patrimônio disponibilizado para o endereçamento voluntário, em razão da inexistência de herdeiros necessários.

\footnotetext{
As referências ao Código Civil italiano foram feitas com o devido cuidado de se verificar, na rede mundial de computadores, a redação alual de cada artigo. Para tanto toi utilizado primordialmente o site http:/www.studiocelentano.it/codici/cc/ com o último acesso em 17 de agosto de 2004.

Doutora e Livre Docente em Direito. pela Faculdade de Direitn da Universidade de São Paulo (USP). Professora Associada do Departamento de Direito Civil da Faculdade de Direito da Universidade de São Paulo (USP). Ex Procuradora Federal.

2 OLIVEIRA. Arthur Vasco Itabaiana de. Tratado de Direito das Sucessôes. Sâo Paulo: Max I imonad, 1952. v. 1, p. 169.
} 
Com efeito. morta uma pessoa qualquer, titular de um patrimônio qualquer, este será devolvido àqueles herdeiros que liverem sido nomeados pela vontade do tustador em primeiro lugar e respeitadas eventuais disposiçôes legais que tenham o condão de limitar a vontade do testador - o que emprusta à sucessão testamentária certa prevalência senão sob o ponto de vista da importância, ao menos sob o ponto de vista da ordem cronológica. Não é por outra razão que o Código Civil italiano (CCl) determina que não se pode proceder à sucessão legítima, a menos que se comprove que não subsistirá, ainda que parcialmente, a sucessão testamentária. Esta previsão, contida no art. $457 \mathrm{CCl}^{3}$ traz consigo. então, um modo de garantir o respeito à vontade do testador. Todavia, o mesmo legislador que. por um lado, garante proteção à vontade do testador, o faz apenas em certa medida, uma vez que prevê no mesmo dispositivo legal referido - que as disposições testamentárias não podem prejudicar o direito que a lei reserva aos "legittimari", isto é, àqueles herdeiros legítimos que assumem a especial qualidade de serem os herdeiros necessariamente contemplados com parte da herança. Equivalem, portanto aos herdeiros necessários do direito brasileiro.

Entre nós, e como antes se mencionava, sob a visão de Itabaiana de Oliveira, deve-se notar que o autor define a ordem de vocação hereditária sob a vigência do Código Civil brasileiro de 1916 (CCB/1916), no qual o estabelecimento da ordem de chamada para suceder era verdadeiramente seccionada, vale dizer. era feita por etapas vocatórias que não se interpenetravam e que não admitiam concorrência. como se os herdeiros de primeira ordem subordinassem os herdciros de segunda, os de terceira, ou e os de quarta ordens, inexistindo entre eles qualquer espécie de concorrência, ou seja, inexistindo qualquer chance de coordenação entre herdeiros de classes diferentes, num musmo momento de convocação.

Esta coordenação preferencial descrita por Itabaiana de Oliveira cra, então, uma verdadeira subordinação, verificável em razão da colocação - querida e decidida pelo legislador dos membros da familia em uma ou em outra das ordens de vocaçâo hereditária.

Apenas com a promulgação do Código Civil brasileiro de 2002 (CCB/2002), todavia, é que se pôde verificar a determinação de uma verdadeira coordenação preferencial entre eles. Esta determinação legal - válida para a concorrência dos herdciros nos moldes do CCB/2002 - também o é para as múltiplas hipóteses de concorrência de herdeiros de diversas linhas (reta e colateral, germana e unilateral, por

Art. $457 \mathrm{CCl}:$ " I Non si fa luogo alla successione legittima se" non quando manca, in tutto o in parte. quella testamentaria. [...]" 
exemplo). diversos graus (direito de representação e sucessão dos colaterais atí o scxto grau, por exemplo) ou mesmo de diversa origem (concorrência de cônjuge com descendentes, com ascendentes ou com colaterais de segundo grau), hipóteses todas estas que, como se verá, estão previstas no $\mathrm{CCl}$, numa complexa ordem de vocação hereditária que admite múltiplas concorrêncıas.

No que respeita ao direito brasileiro, o art. 1.829 C.B.B/2002 estabelece a ordem de vocação dos herdeiros de forma bem semelhante àquela verificada no art. 1.603 CCB/1916. ${ }^{4}$ Todavia, neste Código que ora vigora entre nós, os brasileiros, pode-se verificar a concorrência dos cônjuges sobreviventes ou dos companheiros supérstites com os herdeiros das outras ordens de vocação para suceder, sem que, com isso, se tenha desvirtuado a classificação vocatória dos herdeiros, em ordem de preferência, conforme estabelecida pelo legislador.

Nesse sentido, então, permanece absolutamente firme a afirmativa segundo a qual umor primum descendit, deinde ascendit, fórmula latina usada para exprimir a sensação da socicdade no sentido de que os descendentes devem compor sempre o grupo por primeiro chamado a herdar, pois o amor do falecido era, certamente, mais forte em relação a eles, posto que fruto de sua constituição física, de sua estrutura moral e, possivelmente, de seu afeto e de sua comunhão de vida para com o outro genitor, quiçá sobrevivo à sua morte. Em conseqüência disto, também foi sempre pacífica a sensação social de que apenas na falta absoluta de descendentes é que os ascendentes deveriam ser chamados a herdar, uma vez que somente na falta de "energias novas e vigorosas". continuadoras por excelência da vida que acabara de ser ceifada, é que se deveria buscar gerações anteriores à do morto. ${ }^{6}$ Esta máxima é válida ainda para o Direito italiano, pois apesar da complexa carga legislativa que contempla as hipóteses de concorrência fazendo concorrer, às vezes, os descendentes com os colaterais de segundo grau e, outras vezes, os ascendentes com os mesmos colaterais e, todos eles, com o cônjuge sobrevivente

4 Art. 1.603 - A sucessão legitima defere-se na ordem seguinte: I - aos descendentes; II - aos ascendentes; III - ao conjuge supérstite; IV - aos colaterais: V - aos Municipios, ao Distrito Federal ou à União.

5 Fxceto se se tratasse de descendentes exclusivos do falecido, provenientes de uma relação eventual. De certa forma, também se os descendentes forcm fruto de uma relação já extinta (por superveniência de divórcio, separação ou anulação do casamento, ou. ainda, de dissolução da união estável), em que a paternidade ou a maternidade daquele que falece não :iver sido exercida com todo o seu devotamento e sua afeição. Nestes casos, em que a procriação e a paternidade/maternidade não tiverem andado cunjuntamente (cf.. por todos, João Baptista Villela. Desbiologização da paternidade. Revista Forense, v. 271) estar-se-á diante de uma hipótese em que a ordem de vocação hereditária querida e fixada pelo legislador poderá não coincidir com o brocardo latino citado no texto, pois é possivel que não su tenha estabelecido entre o ascendente-falecido c os descendentes-herdeiros, qualquer relação afetiva que autorize dizer que amor primum discendit, dcinde ascendit amor primum descendit, deinde ascendit.

6 Cf. MONTEIRO. Washington de Barros. Curso de direito civil: direito das sucessões. 33. ed. São Paulo: Saraiva, 1999. v. 6. p. 69-70. Trata-se da última edição publicada pelo autor. antes de sua morte. em 1999. 
- fato é que o legislador italiano não previu jamais a concorrência de herdeiros da linha reta descendente com herdeiros da linha reta ascendente, comprovando a verdade da fórmula citada.

Esta máxima permanece absolutamente válida, no âmbito sucessório, portanto. Todavia. o que se verifica, em termos de novidade legislativa brasileira, é a concorrência do cônjuge ou do companheiro supérstites no momento da convocação dos descendentes e dos ascendentes. para que aqueles adquiram, em razão da morte de seu parcciro de conjugalidade (por casamento ou por união estável), uma parcela do patrimônio deixado pelo morto, ainda que dependendo da verificação de certos pressupostos.

2. O sistema díspar de vocaçăo do cônjuge concorrente criado pelo novo código civil brasileiro, dependente do estado civil do autor da herança

O primeiro pressuposto que deve ser vencido, quando da abertura de uma sucessão, para que se possa proceder à correta vocação dos herdeiros . tanto os de chamada própria, como os que serão concorrentemente chamados consiste em perquirir qual o estado civil do autor da herança.

Neste ponto, ao prever a concorrência tanto do cônjuge como a do companheiro, em determinadas hipóteses sucessórias e sob determinadas condições, o novo Código Civil brasileiro passa a estabelecer regras que dependerão da resposta que se dará a esta primeira dúvida, para que, a partir de então, se proceda à correta partição do monte-mor.

Saliente-se que esta questão não necessitou de qualquer cuidado ou tratamento à luz do texto da Lei Civil brasileira de 1916. Com efeito, como àquela época não se fizesse distinção entre união estável e concubinato, não se atribuíam direitos sucessórios, na sucessão legitima, aos então chamados concubinos puros, ou scja, àquelas pessoas qui, embora podendo se casar, preferiram optar simplesmente pela união livre, de esforços conjugados e de aspirações comuns, sem necessidade de qualquer rigor ou formalismo. Esta escolha consciente, àquela época, podia acarretar na infeliz conseqüência do desamparo material - ao lado do possível desamparo moral e espiritual de um dos companheiros por ocasião de sua viuvez.

Além disso, até 1977. com a impossibilidade da dissolução do vínculo matrimonial por divórcio, também não se excluía o separado de fato da sucessão do cônjuge falecido. o que é possivel atualmente, em razão da verificação de certo lapso temporal de separação factual e da existência ou não de culpa do sobrevivente na ruptura da vida conjugal, como se verá adiante. 
Assim. atualmente. e diante das regras estampadas pelo legislador ao longo dos arts. 1.829 a 1.844, lidos em consonância com o art. 1.790, todos do Código Civil de 2002, é possível traçar três diferentes formas de se partilhar o acervo hereditário deixado pela pessoa que falece, conforme fosse o scu estado civil no momento de sua morte.

$\mathrm{Na}$ primeira hipótese, a sucessão se processa relativamente a uma pessoa que, no momento de sua morte, cra casada ou que, sendo casada, estava separada de fato a menos de dois anos, circunstâncias estas nas quais a sucessão processar-se-á de uma forma que levará em consideração, primeiramente, o regime de bens do casamento ora desfeito por morte. Também se enquadram nesta hipótese, e sob esta forma de partilhar, aquelas pessoas que, ainda que separadas de fato a mais de dois anos, não tenham se separado por culpa própria, devendo, então. disto fazer prova para efeilo do chamamento pretendido.

Na segunda hipótese, a sucessão se verifica relativamente a uma pessoa que vivia em união ustável, circunstância esta na qual, ante o silêncio dos companheiros, terá vigorado entre eles a normativa supletiva estabelecida pelo legislador, que lhes faz incidir as regras atinentes ao regime da comunhão parcial de bens (CC, art. 1.725). Nesta hipótese, o que será levado em consideração no momento da divisão do monte partível é a forma de aquisição (onerosa) dos bens a serem partilhados, como se pode depreender do caput do art. 1.790 da legislação em vigor.

Por fim, a derradeira hipótese dirá respeito aos casos em que o defunto tiver falecido sem deixar cônjuge sobrevivente que, como tal, pudesse ser considerado herdeiro -.. mas sem deixar, também, um companheiro de vida. Nestes casos. porquanto não se vá verificar nem a concorrência do cônjuge, nem a do companheiro na partição da herança, as regras aplicáveis serão em tudo muito parecidas com as regras vigentes no Código de 1916. Trata-se da sucessão dos viúvos, dos soltciros, dos divorciados e separados judicialmente ou dos separados de fato a mais de dois anos, cuja razão pela impossibilidade da manutenção da vida em comum não pudesse ser imputada ao cônjuge que ao outro sobreviveu.

Seja qual for a hipótese que estiver configurada, o intérprete deverá partir da análise do art. 1.829 do CC/2002. mas lembrando-se da existência do art. 1.790, relativo às sucessões de pessoas que viviam em união estável. É certo que ambos os artigos referem-se à ordem de vocação hereditária, mantendo em essência a regra de que primeiro são chamados os descendentes do autor da herança, eventualmente em concorrência com o cônjuge ou o companheiro supérstites. Se faltarem os descendentes, serão chamados a herdar os ascendentes do falecido, eventualmente em concorrència com o cônjuge ou o companheiro supérstites. Em terceiro lugar scrá chamado a herdar o 
cônjuge sobrevivente, se houver. Em quarto lugar, serão chamados a herdar todos os parentes colaterais, até o quarto grau de parentesco, estabelecendo-se entre eles uma certa ordem legal de preferencia, podendo ocorrer, se for o caso, a concorrência destes colaterais com o companheiro supérstite. Por fim, na última urdem de vocação hereditária, e a teor do art. 1.790, será chamado a herdar o companheiro do falecido, a ele sobrevivente. Como bem se vê, é evidente a falta de sistema e de coerência existente entre esses dois dispositivos do novo Código (arts. 1829 e 1790), mormente levando-se em conta que o art. 1790 se encontra topicamente mal localizado no corpo legislativo, como se fosse uma infeliz inserção de última hora que não tivesse obedecido à regra eqüalizadora da própria Constituição Federal brasileira.

O novo Código Civil, por outro lado, e atendendo a reclamo antigo da doutrina, retirou o Poder Público da ordem de vocação hereditária, reconhecendo que o Estado não é herdeiro, mas mero destinatário dos bens vagos, o mesmo acontecendo no direito italiano, muito embora uma leitura apressada do art. $565 \mathrm{CCI}$ possa dar a falsa impressão de estar o Fstado arrolado na ordem de vocação hereditária. Todavia, o art. 586 $\mathrm{CCI}$ é claro ao dizer que na falta de parentes sucessíveis a herança se devolve ao Estado que adquire o patrimônio vago de direito, sem necessidade de aceitação e sem qualquer hipótese de renúncia por sua narte. Este mesmo artigo garante que o Fstado, nesta situação, não responde pelas dívidas da herança, nem pelo pagamento dos legados, senão nos limites da força da herança.

\subsection{A sucessão de quem era casado ou era separado de fato há menos de dois anos}

Nesta primeira hipótese, como antes mencionado, a sucessão se processa relativamente a uma pessoa casada e que assim permanecia, ou que, embora casada, estivesse separada de fato há menos de dois anos. Também se enquadram nesta hipótese aquelas pessoas que, mesmo estando separadas de fato há mais de dois anos, não tenham se separado por sua própria culpa, devendo disto fazer prova.

Este pressuposto de não-culpa não quer significar, todavia, que o morto tenha sido, obrigatoriamente, o culpado exclusivo pela ruptura da vida em comum, nem mesmo que tenha havido culpa. Com efeito, o art. $1.830 \mathrm{CCB} / 2002$ determina que aquelas pessoas que estiverem separadas de fato há mais de dois anos sejam afastadas da sucessão, a menos que o sobrevivente consiga provar que a ruptura da vida em comum não ocorreu por culpa sua.

Da leitura deste ariigo, quatro hipóteses apresentam-se como possiveis:

(i) o falecido foi o culpado pela separação de fato; 
(ii) o sobrevivente foi o culpado pela separação de fato;

(iii) ambos foram culpados pela separação de fato;

(iv) não houve culpa de quem quer que seja pela separação de fato.

Ora, a interpretação do art. $1.830 \mathrm{CCB} / 2002$ só pode significar que se a culpa por tal impossibilidade foi exclusiva do morto (i), ou se não houve culpa de ninguém (iv), tendo havido, neste caso. mero acordo (tácito ou expresso) no sentido de uma separação fática, sem imputação de culpa da parte de quem quer que seja, o cônjuge sobrevivente, mesmo que separado de fato, irá participar da sucessão, concorrendo nas duas primeiras ordens de vocação hereditária, ou amealhando a totalidade do acervo, se a vocação chegar até a terceira ordem sucessória.

Será, todavia, afastado da sucessão caso se demonstre comprovado que a culpa pela separação foi exclusivamente dele, o cônjuge sobrevivente, ou mesmo quando se concluir que tenha havido culna concorrente, imputável a ambos os membros do casal separado faticamente há mais de dois anos.

Vencidas estas premissas, cumpre seguir na leitura do art. $1.829 \mathrm{CCB} / 2002$ que determina a concorrência dos descendentes do morto com o cônjuge supérstite deste, segundo o regime de bens que tenha vigorado durante a vivência matrimonial.

Art. 1.829. A sucessão legitima defere-se na ordem seguinte:

$I$ - ucs descindentes, em concorrência com o cônjuge sobrevivintc. salvo se casado este com o falecido no regime da comunhão universal, ou no da separação obrigatória d' bens (art. 1.641), parágrafo único); ou se, no regime da comunhão parcial, o autor da herança näo houver deixado bens particulares;

Da leitura do primeiro inciso do art. $1.829 \mathrm{CCB} / 2002$ pode-se perceber que existe uma séria limitação relativamente ao regime de bens que vigorou durante o matrimônio.

Com efeito, se os cônjuges eram casados pelo regime da comunhão universal de bens, entende o legislador que a confusão patrimonial já se operara desde a celebração das núpcias, garantindo-se ao cônjuge sobrevivo pela meação que the assiste - a proteção necessária e cabível na espécie, além de demonstrar "a colaboração que cada um dos cônjuges prestava ao outro na conservação c frutificação dos bens já existentes no casal e daqueles que, entretanto viessem a ser adquiridos" 7

De outra forma, os casados pelo regime da separação obrigatória de bens

7 PITÃO. José António de França. A posição do cônjuge sobrevivo no actual dircilo sucessório porluguês. 3. ed. Coimbra: Almedina, 1994, p. 15. Segundo o autor, o viúvo encontraria já sua garantia no "conjunto das relações patrimoniais da família" (p. 17) representada pela meação. 
(art. 1.641 CCB/2002 e não 1.640 CCB/2002, como consta do texto legal, por engano de redação) estão impedidos por lei de estabelecer regime patrimonial diverso e acabam afastados, pelo legislador, da concorrência con us descendentes, na primeira chamada para herdar.

Relativamente ao regime da separação convencional de bens, por outro lado. não existem ressalvas impostas pelo legislador que. tendo se calado, parece ter permitido a concorrência na primeira ordem de vocação hereditária, ocorrendo o mesmo relativamente ao regime da participação final dos aqüestos.

Por fim, quanto ac regime da comunhão parcial de bens, impõe o legislador uma dualidade de tratamento para os que, tendo sido casados sob este regime de regência patrimonial, possuissem ou-não bens particulares. Neste caso, então, a lógica interpretativa se faz pelo seguinte viés: aqueles bens que compõem o patrimônio comum do casal são divididos, não em razão da sucessão, mas tão-somente em virtude da dissolução da sociedade conjugal, operando-se, via de conseqüência, a separação das meações que tocavam a cada um dos membros do casal; por outro lado. os bens exclusivos do autor da herança, relativamente aos quais o cônjuge sobrevivente não tem direito à meação, serão partilhados entre ele. sobrevivo (em razăo da concorrência), e os descendentes do autor da herança, em razão da sucessão causa mortis. ${ }^{\circledR}$

Verificada a forma de partilha, segundo o regime de bens adotado pelo autor da herança em seu casamento, deve-se proceder à verificação de quais os descendentes que serão chamados a hurdar, não sem antes deitar a atenção para o fato de que o cônjuge sobrevivente fará jus ao direito real de habitação da moradia da família, sempre que este imóvel seja o único desta espécie a inventariar e sem prejudicar a parlicipação eventual do cônjuge na distribuição e sucessão dos bens, mortis causa (art. 1.83। CCB/2002).

A regra geral é que os descendentes sejam chamados de grau em grau,

8 Uma explicação se faz necessária. Relativamente à sucessão de pessoas casadas no regimu da comunhão parcial de bens. em que haja a concortência do cônjuge sobrevivo, por existirem bens particulares pertencentes ao morto, esta autora tem se posicionado, sempre, no sentido de que entram na partilha que favorecera o cônjuge sobrevivente apenas os bens particulares do falccido. uma vez que esta parece ser a mens legis expressa no Códiço Civil de 2002. Este posicionamento está expresso nos comentários da autora ao Código Civil publicados pela Editora Saraiva, de São Paulo, com cuordenação do profecssor Antonio Junqueira de Azevedo. O volume que coube à autora ć o de número 20. que abarca os artigos relativos à sucessão em geral e à sucessão legítima. Por outro lado. na qualidade de co-autora do volume 6 do Curso Avançado de Direito Civil, publicado pela Editora Revista dos Tribunais, de São Paulo, consta posicionamento diverso a este aqui esposado. Nesta última obra citada. a esta autora incumbiu escrever a respeito da sucessão testamentária, sendo cento qui os temas relativos à sucessão em geral e à sucessão legitima são da lavra do co-autor daquela obra, professor Francisco José Cahali. Em razão de nossas divergências a respeito dcste tema, principalmente. os capílulos. que já eram assinados individualmente na primeira edição daquela obra tem, agora. na segunda e mais recente edição, os nomes de scus autores no cabeçalho de todas as páginas. como forma de bem esclarecer a autoria das idéias ali consignadas. 
sendo certo que os parentes de grau mais próximo excluem os mais remotos (art. 1.833 CCB/2002). Neste sentido, então, em primeiro lugar serão chamados a suceder os filhos do autor da herança. Na falta destes, chamar-se-ão os netos e posteriormente os bisnetos, ressalvando-se a possibilidade de haver representação dos descendentes do autor da herança, pré-mortos, por seus próprios descendentes. Esta vocação ocorre sem limitação de grau, que não aquela limitação determinada pela própria finitude da vida humana que impede a convivência de gerações mais distantes.

Na sucessão dos descendentes, em concorrência com o cônjuge sobrevivo, a legislação vigente determina qui sc reserve uma quarta parte do monte partível, pelo menos, para que esta seja entregue ao viúvo, se este concorrer com herdciros que sejam também descendentes seus. Assim, se o autor da herança tiver tido filhos de um único leitu (o leito conjugal), o cônjuge sobrevivente, co-genitor dos descendentes do autor da herança amealhará pelo menos $25 \%$ do monte partivel.

Por outro lado, e a contrario sensu, percebe-se que a concorrência do cônjuge com descendentes dos quais não seja ascendente implica na atribuição de uma quota parte idêntica àqucla atribuída aos descendentes do morto, sejam quantos forem, não havendo, portanto, a reserva da quarta parte.

Trata-se de uma opção do legislador que se explica pela presunção legal de que a reserva da quarta parte apenas ao ascindente dos descendentes comuns (ao falecido e ao sobrevivente) será, mais cedo ou mais tarde, deferida a estes descendentes, posto que serão eles os herdeiros do ascendente-herdeiro concorrente.

Questão mais tormentosa que se busca solucionar, relativamente a essa concorrência prevista pelo dispositivo em comento, é aquela que vai desenhar uma hipótese em que são chamados a herdar os descendentes comuns (ao cônjuge falecido e ao cônjuge sobrevivo) e os descendentes exchusivos do autor da herança, todos herdando em concorrência com o cônjuge sobrevivo. O legislador do Código Civil de 2002, cmbora inovador na construção legislativa de hipótese de concorrência do cônjuge com herdeiros de convocação anterior à sua própria, infelizmente não fez a previsão da hipótesc agora em apreço, de chamada de descendentes dos dois grupos, quer dizer, os descendentes comuns e os descendentes exclusivos. E é bastante curioso, até, observar essa lacuna deixada pela nova Lei Civil, uma vez que em nosso país a situação descrila é comuníssima, isto é, a situação de famílias que são constituídas por pessoas que já foram unidas a outras, anteriormente, por casamento ou-não, resultando dessas uniões fïlhos (descendentes, enfim) de origens diversas.

A dúvida que remanesce, à face da ausência de previsão legislativa para uma hipótese assim, diz respcito, afinal, ao fato de se buscar saber se deve prevalecer, ou 
não, aquela reserva da quarta parte dos bens a inventariar, em favor do cônjuge sobrevivo que concorre com os descendentes herdeiros.

Ora, a maneira que escolhcu o legislador para redigir o art. 1.832 nāo deixa nenhuma dúvida acerca da intenção de se dar tratamento preferencial ao cônjuge sobrevivo, quando se trata de concorrência com descendentes do de cujus que sejam também seus descendentes, exatamente lhe reservando esta quarta parte da herança, como quinhão mínimo a herdar, por concorrência com aqueles. Observe-se que o legislador não fez idêntica referência para a hipótese distinta, vale dizer, de serem os herdeiros, com quem concorre o cônjuge sobrevivo, descendentes exclusivos do falecido. Logo, esta foi, sem dúvida, a opção do legislador civil brasileiro * a de privilegiar o cônjuge concorrente com a reserva da quarta parte da herança, apenas no caso de concorrência com herdeiros dos quais elc fosse ascendente - e, por esta razão, a opção legislativa (a mens legis) passa a valer como paradigma para a exegese do regramento, pelo futuro doutrinador, bem como pelo futuro aplicador do direito, tudo em prol de uma sadia consolidação jurisprudencial do porvir.

Se este foi o espírito que norteou a concreção legislativa no novo Código Civil e trata-se de uma formulação bastante elogiável -, entendo que ele deva ser preservado, ainda quando se instale, na vida real, a hipótese híbrida" antes considerada, de chamamento de descendentes a herdar, de ambos os grupos, isto é, de descendentes que também o sejam do cônjuge concorrente, e de descendentes exclusivos do autor da herança. Qualquer solução que pretenda deitar por terra essa escolha paradigmática consagrada pelo legislador brasileiro deveria estar consignada em lei, ela também, exatamente para evitar a variada gama de soluções que terá de ser, obrigatoriamente, organizada pelo hermeneuta e pelo aplicador do direito. formulando respostas jurisprudenciais que não guardem correlação alguma com aquele espirito do legislador, claramente registrado no artigo em comento (n. 1.832).

Mas porque não há. na nova Lei Civil, uma disposição específica para a hipótese híbrida (descendentes comuns e descendentes exclusivos), soluções judiciais alternativas serão certamente levantadas para os casos que se apresentarem no interregno de tempo que se estenderá entre a entrada em vigor do Código ${ }^{10}$ e a necessária alteração legislativa, no porvir.

9 Denomino hipótese hibrida aquela situação familiar antes retratada. na qual o falecido deixa como herdeiros descendentes seus de distinta origem. vale dizer, uns que são descenclentes commus a ele próprio (o lalecido) e o cônjuge que sobrevive e outros que são descendentes exclusivos dele (o falecido, autor da herança). Trata-se de um modo pessoal que inauguro e que se destina a denominar aquela situação retratada de forma mais singela, evitando que, a cada menção, seja necessário repetir a exaustiva explicação da hipótese.

O Código Civil brasileiro, Lei n. 10.406. de 10.01.2002, entrou em vigor em 11.01.2003. 
Se assim for, então, parecem ser três as mais prováveis propostas de solução para as ocorrências hibridas de sucessão de descendentes dos dois grupos (comuns e exclusivos) em concorrência com o cônjuge sobrevivente.

- la proposta: identificação dos descendentes (comuns e exclusivos) como se todos fossem também descendentes do cônjugc sobrevivente

Por esta via, que considera todos os descendentes do de cujus como sendo descendentes também do cônjuge sobrevivo, a conseqüência seria a se determinar que se rescrvasse a quarta parte do monte hereditário (sobre o qual incide a concorrência) a favor do cônjuge concorrente. Solução assim representaria, no entanto, um certo prcjuízo aos descendentes exclusivos do falecido, os quais - por não serem descendentes do cônjuge com quem concorrem - ficariam privados de receber uma parte mais substanciosa do patrimônio exclusivo de seu ascendente morto.

Além disso e como já se mencionou antes … uma solução como esta poderá ser objeto de crítica, por parte de certo segmento hermeneuta, sob a alegação de que. aplicando-a, não se satisfará o espirito do legislador do novo Código Civil, uma vez que este pretendeu privilegiar o cônjuge supérstite dirão estes críticos - nestas condições de reserva de parte ideal tão-somente quando tal cônjuge fosse também ascendente dos herdeiros de primeira classe com quem concorresse. Ora, se submetida a esta crítica, tal proposta não suportaria prevalecer como possivel, não-obstante garanta quinhões iguais aos filhos de ambos os grupos (comuns e exclusivos).

$2^{\mathrm{a}}$ proposta: identificação dos descendentes (comuns e exclusivos) como se todos fossem descendentes exclusivos do cônjuge falecido

Da mesma forma com a qual se cuidou de refutar a proposta anterior, também aqui se pode chegar à mesma conclusão de inobservância do espirito do legislador do Código Civil. Mas, aqui, tal inobservância se verifica na exata medida em que o tratamento de todos os descendentes do de cujus como se fossem seus descendentes exclusivos, acabaria por dispensar a obrigatoriedade de reserva da yuarta parte do monte partivel em favor do cônjuge sobrevivo, como forma de lhe garantir um maior amparo em sua viuvez.

Tratá-los (aos descendentes todos, comuns e exclusivos) como se fossem descendentes exclusivos do falccido representa solução que curtamente desconhecerá a mens legis do dispositivo legal $\mathrm{cm}$ comento que - embora padeça do defeito de não ter feito a previsão de aferição matemática para a hipótese de concorrência do cônjuge com 
herdeiros descendentes comuns e exclusivos - inegavelmente contém uma carga positiva a favor do cônjuge concorrente, quando the garante, minimamente, a reserva da quarta parte do acervo heredilário subré o qual incidirá a concorrência.

- $\quad 3^{a}$ proposta: composição pela solução híbrida, subdividindo-se proporcionalmente o monte partível sobre o qual incide a conconència, segundo a quantidade de descendentes de cada grupo

Por esta via de raciocínio (que bem poderia ser intentada pelo intérprete, à face da lacuna do legislador), a divisão patrimonial do acervo obedeceria às seguintes regras: primeiro se dividiria o monte partivel em dois sub-montes. proporcionalmente ao número de descendentes de cada um dos grupos (comuns e exclusivos). O submonte que fosse destinada a compor os quinhões hereditários dos descendentes exclusivos seria dividido em tantas quotas quantos fossem os herdeiros desta classe, mais uma (correspondente à quota do cônjuge concorrente. conforme delerminação do art. 1.832, primeira parte), entregando-se a cada um dos herdeiros o seu correspondente quinhão hereditário. A seguir, dividir-se-ia, da mesma maneira, o submonte destinado a compor os quinhões hereditários dos descendentes comums, pelo número deles, mais um, destinado ao cônjuge que com eles concorre. Supondo que a soma das quotas deferidas ao cônjuge sobrevivente - em concorrência com descendentes comuns $\left(1^{\circ}\right.$ submonte) e em concorrência com descendentes exclusivos ( $2^{\circ}$ submonte) - fosse menor que a quarta parte do total do monte partivel (sobre o qual incidisse a concorrência), é provável que o aplicador de uma tal interpretação determinasse a reorganização da divisão, para que o preceito do legislador ordinário pudesse ser observado. Para tanto, é provável que a saída escolhida pelo hermeneuta fosse a de se abater do sub-montc atribuivel aos descendintes comuns o quanto fosse necessário para somando-se ao quinhão do cônjuge obtido pela partilha do sub-monte dos descendentes exclusivos - consolidar o equivalente a $25 \%$ do total do monte partivel (atendendo, assim, ao que dispõe a segunda parte do mesmo dispositivo legal em comento, o art. 1.832 do Código Civil brasileiro).

Ora, é muito fácil observar que. senão em excepcionalíssima circunstância real, essa composição matemática não conseguiria atender aos preceitos legais envolvidos (arts. 1.829, I, ¿ 1.832), mas principalmente não garantiria a igualdade de quinhões atribuiveis a cada um dos descendentes da mesma classe, conforme determina o art. 1.834, dispositivo legal de caráter constitucional que determina que "os descendentes da musma classe têm os mesmos direitos a sucessão de seus ascendentes" Quer dizer, nem se conscguiria obter - por esta proposta imaginada salomonicamente conciliatória - iguais 
quinhões para os herdeiros da mesma classe (comuns ou exclusivos), nem seria razoável que a quarta parte garantida ao cônjuge fosse complementada por subtração levada a cabo tão-somente sobre a parte do acervo destinada aos descendentes comuns.

De qualquer das formas, ao que parece, na ocorrência de uma hipótese real de sucessão de descendentes que pertencessem aos dois distintos grupos (comuns e exclusivos) em concorrência com o cônjuge sobrevivo, não haveria solução matemática que pudesse atender a todos os dispositivos do Código Civil novo, o que parece reforçar a idéia de que há nele uma falha legislativa tão significativa que impede a solução, pelo viés singelamente interpretativo, da situação de concorrência do cônjuge sobrevivo com descendentes de origem híbrida. Bem por isso, e para evitar uma profusão de inadequadas soluções jurisprudenciais futuras, o ideal mesmo seria que o legislador ordinário revisse a construção legal do novo Diploma Civil brasileiro, para estruturar um arcabouço de preceitos que cobrissem todas as hipóteses, inclusive as hipóteses hibridas (como as tenho chamado) evitando o dissabor de soluções e/ou interpretações que corressem exclusivamente ao alvedrio do julgador ou do hermeneuta, mas desconsiderando tudo aquilo que. a princípio, norteou c ideal do legislador, formatando o espirito da norma. "

$\mathrm{Na}$ falta de descendentes, serão chamados a suceder os ascendentes do falecido, também em concorrência com o cônjugc supérstite. Na hipótese do inc. II do art. $1.832 \mathrm{CCB} / 2002$, não existc qualquer limitação para a concorrência do viúvo ou da viúva assentada no regime de bens do casamento. Assim, seja qual for o regime de bens e seja qual for a origem dos bens (comuns ou particulares), o cônjuge sobrevivente concorrerá com os ascendentes do falecido segundo as regras dos arts. $1.836 \mathrm{e} 1.837$, ambos $\mathrm{CCB} / 2002$.

Assim, o chamamento dos ascendentes iniciar-se-á pelos de grau mais próximo, posto que estes excluem os de grau mais remoto. Neste sentido, os primeiros a serem convocados para adir à herança são os pais do de cujus, em concorrência com o

\footnotetext{
A respeito. vale a pena recuperar a cuidadosa lição de Gustavo Tepedino na mais recente obra sob sua coordenação e intitulada A parle geral do novo Código (ivil: estudos na perspectiva civil-constitucional (verificar "Crise de fontes normativas e técnica legislativa na parte geral do Código Civil de 2002". p. XXI): "Volta-se a ciência juridica à busca de técnicas legislativas que possam assegurar uma maior efelividade ans critérios hermenêuticos. Vesta dirç̧ão. parece indispensável, embora não sufíciente. a deliniçiōo de princípios de tutela da pessoa humana [...]. bem como sua transposição na legislaçào infraconstitucional. O legislador percube a necessidade de definir modelos de conduta (standards) delincados a luz dos princípios que vinculam o intérprete, seja nas siluaçòes juridicas tipicas, seja nas situações não previstas pelo ordenamento. Daqui a necessidade de descrever nos texios normativos (c particularmente nos novos códigos) os cânones hermenèuticos e as prioridades axiológicas, os contornos da tutcla da pessoa humana e os aspectos centrais da identidade cultural que se pretende proteger, ao lado de normas que permitem, do ponto de vista de sua estrulura e função. a necessária comunhào entre o preceito norınativo e as circunstàncias do cuso concreto" ("Crise de fontes normativas e técnica legislativa na parte geral do Código Civil de 2002". A parle geral do) novo Código Civil: estudos na perspectiva civil-constitucional, p. XXI).
} 
cônjuge supérstite. Sigundo a primeira parte do art. 1.837 CCB/2002, a hurança será dividida igualmente entre o pai, a mãe e o cônjuge, cabendo a cada qual um terço da herança.

Por outro lado, se apenas um dos genitores do morto puderem, por qualquer razão, sucedê-lo, ao cônjuge sobrevivente tocará metade do acervo hereditário, entregando-se ao genitor herdeiro a outra metade. Na linha reta ascendente não há direito de representação, motivo pelo qual havendo um único genitor vivo, não se deve convocar os avós, pais do genitor falecido, para representar o seu filho na sucessão.

Outra hipótese possível é a de que ambos os genitores tenham pré-morrido ao filho, ora autor da herança. Neste caso, com a falta de ascendentes de primeiro grau do de cujus scrão convocadas para a sucessão as linhas ascendentes de segundo grau, ou seja, os avós maternos e os avós paternos. Supondo-se que os quatro avós sejam vivos, a eles tocará, por linha, a divisão de metade do acervo, quando cada um dos avós receberá uma oitava parte da totalidade da herança, uma vez que o final do art. 1.837 C C B/2002 determina que o cônjuge sobrevivente herde, sozinho, a outra mutade.

Se, todavia, apenas um dos avós tiver condições de representar uma das linhas e se, na outra linha, ambos os avós puderem representá-la na sucessão, cada uma das linhas receberá um quarto do acervo hereditário, tocando a outra metade ao cônjuge sobrevivo. Na linha onde apenas um dos avós é vivo, este receberá a yuarta parte da herança. Na outra linha, por sua vez, a cada avô será entregue uma oitava parte do monte.

Em um outro cenário, quando houver um avô em cada linha, a herança atribuida ao cônjuge sobrevivente permanece invariável, sendo-lhe deferida metade do acervo; a outra metade será partilhada entre as duas linhas, cabendo um quarto da herança a cada uma delas, sem necessidade de se proceder a outra divisão, na exata medida em que haja apenas um avô paterno e outro materno.

Se houver representantes em apenas uma das linhas, por outro lado, metade da herança será entregue ao cônjuge sobrevivente e a outra metade será deferida à linha representada, subdividindo-se esta parte do acervo entre o avô e a avó, cabendo a cada um deles um quarto do monte partível. Por fim, se houver apenas un dos avós em condição de herdar, este amealhará a metade da herança que não tiver sido entregue ao cônjuge sobrevivente.

$\mathrm{Na}$ falta de ascendentes, a herança de pessoa que tenha falecido enquanto casada ou separada de fato nas condições acima expostas, será deferida, por inteiro, ao cônjuge sobrevivente, segundo o que determina o art. 1.838 CCB/2002. 
2.2. A sucessão de pessoa que era unida estavelmente

A sucessão de pessoa que falece durante a constância de uma união estável está adstrita às regras do art. $1.790 \mathrm{CCB} / 2002$ que deve sur lido em consonância com o art. 1.829 do mesmo diploma, que estabelece a ordem da vocação hereditária.

Cumpre transcrever o art. 1.790:

Art. 1.790. A companheira ou o companheiro participará da sucessão do outro, quanto aos bens adquiridos onerosamente na vigência da união estàvel, nas condişōes seguintes:

I se concorrer com filhos comuns, tera direito a uma quota equivalente ù que por lei for alribuida ao filho:

II se concorrer com descendentes só do autor da herança, tocarIhe-á a melade do que couber a cada um daqueles;

III - se concorrer com outros parentis sucessiveis, terá direito a um terço da herança;

IV năo havendo parentes sucessiveis, terá direito à totalidade da herança.

A sucessão de pessoas que vivam em união estável no momento de sua morte não dependerá, para a concorrência do companheiro com os demais herdeiros, da verificação do regime de bens adotado por contrato de convivência ou mesmo por forma tácita, acatando as regras do reg me legal por força de disposição legal supletiva - ainda que esta opção legislativa pareça extremamente injusta. por desconsiderar a equalização entre cônjuge e companheiro, determinada pela Constituição Federal brasileira - mas dependerá, sim, da origem dos bens que componham o acervo hereditário deixado pelo de cujus.

Assim. o companheiro sobrevivente participará da sucessão do outro apenas quanto aos bens adquiridos pelo de cujus, onerosamente, na vigência da união estável, ou seja, a concorrência se dará justamente nos bens a respeito dos quais o companheiro já $\epsilon^{\prime}$ meeiro. Desta forma, se o companheiro falecido não tiver amealhado quaisquer hens na constância da união estável, ainda que possuísse um enorme patrimônio anterior, o companheiro sobrevivente restará afastado da sucessão, sejam quais forem os herdeiros eventualmente existentes.

Além disso, outra diferenciação - em decorrência, ainda, do estado civil que uniu o morto e o sobrevivente - diz respeito à extensão da restrição relativa ao regime de bens ou à origem do patrimônio. Assim, se para as pessoas casadas o direito a concorrer era restringido pelo tipo de reginc de bens vigente - e apenas na hipótese de concorrência do cônjuge sobrevivo com os descendentes do morto, uma vez que a regra limitativa veio expressa no inciso I do art. $1.829 \mathrm{CCB} / 2002$ - a restrição da espécie de bens sobre os 
quais deverá incidir a concorrência do companheiro sobrevivente está expressa no caput do art. $1.790 \mathrm{CCB} / 2002$, irradiando seus cfeitos por toda a construção legislativa estabelecida pelos seus incisos.

No primeiro inciso, a lei determina que o companheiro sobrevivente que concorrer com filhos comuns a ele e ao falecido amealhará uma quota parte do acervo hereditário igual à que, por lei, for atribuído a cada um dos lillhos. Se se comparar esta regra com a norma atinente à concorrência do cônjuge com os descendentes comuns, verificar-se-á que o legislador não determinou a reserva da quarta parte da herança ao companheiro sobrevivente, tal como houvera feito a respeito da concorrência do cônjuge, em igual circunstância, o que, mais uma vez parece desatender ao comando constitucional de equalização de cônjuges e companheiros.

Em seguida o legislador estabeleceu, no segundo inciso do art. 1.790 $\mathrm{CCB} / 2002$, que a concorrência do companheiro sobrevivente com descendentes exclusivos do morto dar-se-á de forma a que o companheiro receba a metade da quota parte que venha a ser deferida aos descendentes apenas do de cujus. Do ponto de vista prático, então, a partilha se faz na proporção de dois para um. entregando-se ao companheiro sobrevivente uma parte da herança e a cada um dos descendentes, duas partes idênticas àquela entregue ao companhciro sobrevivo.

No que diz respeito à sucessão do companheiro, em concorrência com os herdeiros de primeira vocação quer dizer, os descendentes - se observa que o legislador civil atual pretendeu, efetivamente, dar distinto tratamento a essa sucessão concorrente, aplicando distintas imposições matemáticas se os descendentes fossem filhos do companheiro supérstite e do companheiro falecido, ou se, por outro lado, fossem descendentes exclusivos do autor da herança (incisos I e Il do art. 1.790 do CC, respectivamente), fazendo-o herdar a mesma porção deferida aos filhos comuns e metade da porção cabivel aos descendentes exclusivos do de cujus.

Registre-se que não há razão - no entendur desta autora - que justificasse o fato de o dispositivo sob análise ter determinado concorrência com filhos (exclusivamente), no inciso I ¿ ter determinado concorrência com descendentes (de qualquer grau), no inciso II. O legislador brasileiro deu, portanto. um tratamento preferencial ao companheiro sobrevivo quando se tratar de concorrência com filhos comuns a ele e ao morto. Esta foi a opção do legislador civil brasileiro, ainda que sujeita a crítica, e ela passa a valer como paradigma para a exegese do regramento. pelo futuro doutrinador, bem como pelo futuro aplicador do direito, pelo tempo em que prosseguir em vigur o referido dispositivo de lei.

Registre-se. igualmente, que o legislador brasileiro, neste passo, não fez. 
também qualquer menção à quarta parte que devesse, ou não, ser resguardada a favor de companheiro supérstite, do modo como houvera feito antes, no caso de concorrência de cônjuge com descendentes.

Não bastassem estes descompassos mencionados, o certo é que o legislador brasileiro também trouxc mais um ponto de alta polêmica interpretativa, no que diz respeito à aplicabilidade das regras contidas no artigo ora em análise (art. 1790, incisos I e II, principalmente), qual seja, não houve também aqui, como no caso da concorrência do cônjuge com descendentes, como antes visto a previsão da tormentosa, mas muito comum hipótese de serem herdeiros do falecido pessoas que guardem relação de parentesco (fíliação) com o sobrevivo, em concorrência com outras que fossem parentes apenas dele, autor da herança. Vale dizer, o legislador se olvidou mais uma vez de cuidar da hipótese relativa a autores da herança que deixaram companheiro sobrevivente e que tiveram filhos de outro leito, anterior ou posterior à união estável, mas que os tiveram deste outro relacionamento, constituindo, assim, um conjunto de filhos que se costuma denominar exclusivos e comuns (estes últimos havidos com o convivente que sobreviveu ao scu falccimento).

Dito por outro modo, não há, na nova Lei ( ivil, uma disposição que regulamente esta situação hibrida quanto à condição dos filhos do falecido (comuns e exclusivos), com os quais deva concorrer o companheiro supérstite.

Neste caso, restou a dúvida: ou bem se fazia o companheiro supérstite concorrer com os descendentes de ambas as condições (comuns e exclusivos) como se fossem todos descendentes comuns aos dois, herdando, portanto a mesma quota cabível a cada um dos filhos, ou bem se fazia o companheiro supérstite conconer com os mesmos hurdeiros como se fossem todos descendentes exclusivos do autor da herança. purcebundo, portanto, a metade dos bens que couber a cada qual.

Não bastassem essas duas modalidades exegéticas para a apreciação da circunstância hibrida (existência de filhos comuns e de fillhos exclusivos, en. concorrência com o companheiro sobrevivo), outras duas, aos menos, se apresentaram na considuração doutrinária inaugural: uma que buscou compor as disposições contidas nos incisos I e II do art. 1.790, atribuindo uma quola e meia ao companheiro sobrevivente equivalente à soma das quotas que a ele seriam deferidas, na hipótese de concorrer com filhos comuns (uma) e com filhos exclusivos (meia) -, e outra que igualmente buscou compor as duas regras, dividindu proporicionalmente a herança em ducs sub-heranças. atribuiveis a cada um dos grupos de filhos (comuns ou exclusivos) incorporando. em cada uma delas, a concorrência do companheiro sobrevivo.

Seja qual for a formulação ou critério que se escolha, contudo, a verdade 
que parece torna-se impossível conciliar, do ponto de vista matemático, as disposições dos incisos I e II deste art. I.790.

Parece mesmo não haver fórmula matemática capaz de harmonizar a proteção dispensada pclo legislador ao companheiro sobrevivo (fazendo-o receber o mesmo quinhão dos filhos que tenha tido em comum com o autor da herança) e aos herdeiros exclusivos do falecido (fazendo-os herdar o dobro do quanto dispensado ao companheiro que sobreviver).

Dissa forma, na realidade, são quatro as propostas de tentativas de composição dos dispositivos do Código Civil envolvidos no assunto relativo à sucessão de filhos (comuns ou exclusivos) em concorrência com o companheiro sobrevivente.

- $\quad$ l $^{\mathrm{a}}$ proposta: identificação dos descendentes como se todos fossem filhos comuns, aplicando-se exclusivamente o inciso l do art. 1.790 do Código Civil

Por esta via. a divisão patrimonial obedeceria à simples regra de igualar os filhos de ambos os grupos, tratando-os como se fossem filhos comuns a ambos os companheiros.

Certamente não pode prosperar essa solução simplista, pois se. por um lado, trata de manter igualadas as quotas hereditárias atribuíveis aos filhos (de qualquer grupo), conforme determina o art. 1.834 do Código, por outro lado, fere na essência o espírito do legislador do Código Civil que quis dar tratamento diferenciado às hipóteses de concorrência do companheiro sobrevivo com os descendentes do de cujus de um ou de outro grupo (comuns ou exclusivos).

- $\quad 2^{3}$ proposta: identificação dos descendentes como se todos fossem filhos exclusivos do autor da herança, aplicando-se, neste caso, apenas o inciso II do art. 1.790 do Código Civil

Da mesma forma com a qual se cuidou de relutar a proposta anterior, também aqui, por via desta divisão patrimonial, se chegaria à mesma conclusão, vale dizer, o espírito do legislador do Código Civil restaria magoado, tendo em vista a inobservância da diferença que quis dar às hipóteses de concorrência do companheiro sobrevivo com os descendentes do de cujus de um ou de outro grupo (comuns ou exclusivos).

Nessa hipótese por segundo considerada - e como é possivel observar privilegiar-se-iam os filhos em detrimento do companheiro sobrevivo, que seria tido, sob todos os aspectos como não-ascendente de nenhum dos herdeiros, recebendo, então, 
apenas a metade do que ayueles herdariam. Por outro lado, naquela primeira proposta formulada, o companheiro sobrevivente acabaria por ser privilegiado, na medida em que participaria da herança recebendo quota absolutamente equivalente às quotas atribuiveis aos descendentes de qualquer grupo.

- $3^{\text {H }}$ proposta: composição dos incisos I e Il pela atribuição de uma quota c mcia ao companheiro sobrevivente

Por esta via, a divisão patrimonial obedeccria a seguinte regra: somar-se-ia o número total de fillhos comuns c de filhos exclusivos do autor da herança, acrescentarse-ia mais um e meio (uma quota deferida ao companheiro sobrevivente, no caso de concorrência com filhos comuns, e meia quota deferida ao mesmo sobrevivo, no caso de concorrência com filhos exclusivos do falecido), dividindo-se, depois, a herança por esse número obtido, entregando-se quotas de valores iguais aos filhos (comuns e exclusivos), o que atenderia ao comando de caráter constitucional do art. 1.834 do CC (que determina que descendentes da mesma classc tenham os mesmos direitos relativamente à herança de seu ascendente), c uma quota e meia ao companheiro sobrevivente. o que atenderia aos comandos dos incisos I e II do art. 1.790.

Pode parecur, à primcira vista, que esta solução resolveria - com exemplar facilidade - o problema da partilha, aparentemente atendendo a todas as regras do CC de regência sobre o assunto.

Contudo, a pergunta difícil de responder que fica é a seguinte: se esta for a solução buscada, onde residiria, dentro dela, aquele princípio que norteou o espírito do legislador, ao dar diferentes variáveis de concorrência do companheiro sobrevivo com descendentes de um e de outro grupo (comuns ou exclusivos)? Porque, afinal, o que se vê das quotas hıreditárias e partilháveis entre os filhos todos é que efetivamente elas são iguais, mas a quantia que se abateu da herança, para compor a quota do companhciro concorrente, foi retirada do monte-mor a todos eles idealmente atribuível, sem atentar para a diferença entre os fillhos (como pretendeu diferenciá-los, para esse efeito, o legislador de 2002, nos incisos I e II do art. I.790), diminuindo, igualmente, o quinhão de cada um deles, afinal de contas, para compor a quota hereditária do companheiro concorrente.

O que restou a considerar, num caso como esse, e sob essa solução, é que o tratamento dado ao companheiro sobrevivo foi muito mais privilegiado que em qualquer das duas hipóteses singulares (incisos I e Il do art. 1.790) previstas pelo legislador e vistas cada uma per se. Confira-se: a) se concorresse apenas com filhos comuns, o companheiro 
sobrevivo herdaria quota igual à que coubesse a cada um deles; b) se concorresse apenas com descendentes exclusivos do autor da herança, o companheiro sobrevivo herdaria quora equivalente à metade da que coubesse a cada um deles; c) mas, nessa derradeira, problemática e não prevista hipótese de concorrência com fillhos de ambos os grupos (comuns e exclusivos), o companheiro se bencficiaria, por hcrança. com maior quinhão, qual seja o quinhào equivalente a uma quota e meia, enquanto cada um dos filhos (comuns ou exclusivos) herdaria uma única quota, cada um deles.

Não parece que seja isto que tenha querido o legislador, uma vez que diferenciou as espécies de herdeiros descendentes. para efeito dessa concorrência e, em nenhuma das formulações legislativas, deferiu, ao companheiro sobrevivo, uma quota hereditária maior do que a que coubesse a qualquer dos herdeiros com quem concorresse. $\mathrm{Na}$ melhor das hipóteses (inciso 1), o legislador pensou em igualar o quinhão do companheiro sobrevivo ao quinhão do herdeiro, desde que fosse filho seu e do autor da herança, mas nunca pensou em privilegiar o companheiro com cjuota maior do que a deferida ao herdeiro.

Assim segundo quer parecer a esta autora se aplicado esse critério aqui desenhado, o resultado obtido ao final de uma partilha seria um resultado absolutamente dissociado do espirito do legislador de 2002. Se assim for, não parece ser possível produzi-lo assim simplesmente, tout court.

- $\quad 4^{a}$ proposta: composição dos incisos l e II pela subdivisão proporcional da herança, segundo a quantidade de descendentes de cada grupo

Por esta via, a divisão patrimonial obedeceria à seguinte regra: primeiro se dividiria a herança a ser partilhada entre filhos comuns e filhos exclusivos em duas partes (sub-heranças) proporcionais, cada uma delas, ao número de fillhos de um ou de outro grupo. A scguir se introduziria, em cada uma dessas sub-heranças, a concorrência do companheiro, conforme a deturminação do inciso I ou do inciso Il do art. 1.790, respectivamente. Depois disso, se somariam as quotas do companheiro supérstite obiidas em cada uma dessas sub-heranças - formando o quinhão a ele cabivel. Aos fillhos herdeiros caberia a quota que houvesse resultado da aplicação das regras legais em cada uma das sub-heranças, conforme proposto.

É fácil verificar, se esse fosse o critério a ser utilizado, que os quinhões dos filhos de um grupo seriam proporcionalmente maiores que os quinhões dos filhos do outro grupo. Quinhões desigualados equivalem, entretanto, ao desatendimento do art. 1.834 do CC. dispositivo de caráter constitucional. 
"Além disso, a atribuição ao companheiro de uma quota relativa à subherança dos filhos comuns e de meia quota da sub-herança dos filhos exclusivos do falecido, acabaria por resultar numa somatória de valor superior ao que caberia ao companheiro, se estivesse a concorrer somente com filhos comuns (por exemplo: herança de 50, com dois herdeiros filhos, sendo um, em comum c outro, exclusivo; cada fillho teria a sub-herança de 25; concorrendo com o primeiro, o companheiro concorrente teria uma quota igual à do filho, ou seja, 12,5; concorrendo com o segundo, o companheiro concorrente teria a metade de sua quota, ou seja, 8,3; a soma das quotas do companheiro sobrevivo resulta em 20,8, superior, portanto, à quota de 16,6 à qual ele teria direito, sc estivesse concorrendo com dois filhos, havidos em comum com o falecido)" 12

Assim - segundo quer parecer a esta autora, nesta nova proposta de partição da herança ${ }^{13}$ - se aplicado o critério matemático aqui desenhado, o resultado obtido ao final de uma partilha seria um resultado absolutamente dissociado. não apenas do espirito do legislador de 2002, mas também da principiologia constitucional de fundo. ${ }^{14}$

$\mathrm{O}$ inciso III, por seu turno, determina que na ausência de descendentes do

12 Esta passagem é de Euclides de Oliveira e se contém em correspondência pessoal que manteve com a autora deste trabalho acerca deste artigo. Sui reprodução, neste viés, está devidamente autorizada.

13 Euclides de Oliveira, na correspondência mencionada em nota anterior, deixou consignado que é possivel se levar em conta "uma variante da 3 " proposta, supra, considerando-se que a lei manda atribuir ao companheiro sobrevivente cota igual à do filho comum e só meia quota do filho exclusivo do falecido, seria aplicar a média desses valores, chegando-se à quota de (1,75\%. para as situações de lilhos de hibrida origem. Seria mais justo e adequado à mens legis, pois, em tal circunstância, estaria sendo preservada a quota do companheiro, ainda que proporcional, e os filhos não sofreriam desigualaçào em seus quinhòes". (reprodução autorizada pelo jurista em comento). Tal pensamento deve ser levado em consideração. sem dúvida.

14 O legislador brasilciro, de alguma forma, já se apercebeu da inviabilidade de conexão entre o enunciado genérico contido no art. 1.790, I e Il e a norma descritiva de valores que descreve o art. 1.834, todos do novo Código Civil brasileiro. O Projeto de Lei n. 6.960/2002 (do deputado Ricardo Fiúza) intenta uma nova redação para o arı. 1.790, deixando-o com a seguinte sugestão de redação: "Art. 1.790. O companheiro participará da sucessão do outro na forma seguinte: I - em concorrência com descendentes, terá direito a uma quota equivalente à metade do que ccuber a cada um destes, salvo se tiver havido comunhão de bens durante a união estável e o autor da herança não houver deixado bens particulares. ou se o casamento đos companheiros se tivesse ocorrido, observada a situação existente no começo da convivência. fusse pulo regimc da separação obrigatória (art. 1.64l)"; [...] A alteração de fundo é significativa. pois todo o contono e conteúdo do dispositivo é alterado. Mas não esteve prcocupado o legislador do substitutivo em compor matematicamente a possibilidade de aplicação dos dispositivos do Código Civil tal como estão. hoje. Na substanciosa obra denominada Novo Código Civil Comentado, coordenada pelo próprio deputado Ricardo Fiúza Saraiva, 2002, 1.843p.). o jurista encarregado de comentar esse art. I.790 e de demonstrar a sugestão legislativa de alteração que o acompanha (Projeto de Lei n. 6.960/2002) foi exatamente o insigne Zeno Veloso, que assim descreveu a razão da sugestão legislativa sob comento: "Consciente disso [referia-se aos inúmeros problemas originais do dispositivo]. e considerando o posicionamento assumido no Congresso Nacional, em vez de oferecer ao Deputado Ricardo Fiúza minha própria proposta, vou apresentar - com algumas alteraçōes. a meu ver necessárias - a que foi oferecida pelo Instituto Brasileiro de Direito de Familia

IBDFAM, colocando-a de acordo com as limitações à concorrência dos cônjuges com os descendentes (art. 1.829 ) e com a emenda que sstou propondo ao art. 1.831, que regula o direito real de habitação. Transijo, enfim. para que o art. 1.790 não fique como está" 
murto. o companheiro concorrerá com os outros parentes sucessíveis, recebendo, em qualquer caso. uma terça parte da herança. Desta forma, não importa se tratar de ambos os ascendentes, quando cada um deles receberá também e igualmente - um terço do acervo partilhável, ou de um único tio-avô com quem o falecido não mantinha quaisquer espécies de relações, nem mesmo de ordem social, hipótese em que este receberá dois terços do patrimônio.

Para se saber quem sejam estes parentes sucessiveis a que se refere o inciso III do art. 1.790 CCB/2002, deve-se recorrer ao art. 1.829 e seguintes do mesmo diploma, convocando-se os ascendentes para participarem da sucessão. Assim, um terço do montemor será deferido ao companheiro sobrevivente e os outros dois terços serão divididos entre os ascendentes sobreviventes.

Assim, o chamamento dos ascendentes iniciar-se-á pelos ascendentes de grau mais próximo, posto que estes excluam os de grau mais remoto. Neste sentido, os primeiros a surem convocados para adir à herança são os pais do de cujus, em concorrência com o companhciro supérstite. cabendo a cada qual um terço da herança.

Por outro lado, se apenas um dos genitores do morto puder, por qualquer razão, sucedê-lo, ao companheiro sobrevivente tocará um terço do acervo hereditário, entregando-se ao genitor herdeiro os outros dois terços.

Outra hipótese possível é a de que ambos os genitores tenham pré-morrido au filho. Neste casu, com a falta de ascendentes de primeiro grau do de cujus serão convocadas para a sucessão as linhas ascendentes de segundo grau, ou seja, os avós maternos e os avós paternos. Supondo-se que os quatro avós sejam vivos, a eles tocará a divisão dos dois terços do acervo, quando cada um dos avós receberá um sexto da totalidade da herança, uma vez que o inc. III do art. 1.790 CCB/2002 continue a determinar que o companhuiro sobrevivente herde, apenas, a quantia fixa de um terço do acervo sucessivel.

Se, todavia, apenas um dos avós estiver em condições de representar uma das linhas e se na outra linha ambos os avós puderem representá-la na sucessão, cada uma das linhas receberá um terço do acervo hereditário, tocando a outra terça parte ao companheiro sobrevivo. Na linha onde apenas um dos avós é vivo, este receberá a terça parte da herança. Na outra linha, por sua vez, a cada avô será entregue uma sexta parte do monte.

Em um outro cenário, quando houver um avô em cada linha, a herança atribuída ao companheiro sobrevivente permanece invariável, sendo-lhe deferido um terço do accrvo $\bullet$ as outras duas terças partes serão partilhadas entre as duas linhas, cabcndo um terço da herança a cada uma delas, sem necessidade de se proceder a outra divisão, na exata medida cm qui haja apenas um avô paterno e outro materno. 
Se houver representantes em apenas uma das linhas, por outro lado, um terço da herança será entregue ao companheiro sobrevivente e dois terços serão deferidos à linha representada, subdividindo-se esta parte do acervo entre o avô e a avó, cabendu a cada um deles um terço do monte partível. Por fím, se houver apenas um dos avós em condição de herdar, este amealhará dois terços da herança.

$\mathrm{Na}$ falta de ascendentes, comcçam a ter aplicação os artigos relativos à vocação dos parentes colaterais, uma vez que não haja cônjuge sobrevivente, justamente porque configurada uma união estável.

Assim, serão chamados a herdar, em concorrência com o companheiro subrevivente, os irmãos do morto, parentes colaterais de segundo grau, podendo os irmãos pré-mortos ser representados por seus filhos, que participarão. por estirpe, da sucessão do tio.

A partilha entre os irmãos dar-se-á nos dois terços que não forem entregues ao companhciro sobrevivente, segundo a regra estanque do inc. III do art. I.790 $\mathrm{CCB} / 2002$. Dependerá, no entanto, do fato de serem irmãos bilaterais ou unilaterais.

Irmãos são os parentes colaterais de segundo grau que têm em comum ao menos um genitor. Quando apenas o pai é comum, dizem-se irmãos unilaterais consangüineos, ao passo que se apenas a mãe é comum, dizem-se irmãos unilaterais uterinos. Por outro lado, se ambos os genitores são comuns, os irmãos nestas condições são ditos bilaterais ou germanos.

A distinção é importante. em termos sucessórios, uma vez que a lei restringe a quota parte cabivel aos irmãos unilaterais à metade da quota recebida pelos irmãos bilaterais. Essa restrição, percebe-sc. não leva em consideração os irmãos em si. mas sim a relação do de cujus com os pais do herdeiro.

A lei entende que seria injusto que um irmão unilateral recebesse a mesma quantia que é entregue a um irmão bilateral e isto pode ser explicado por uma ficção que estaria implicita no raciocinio legal. Segundo esta ficção a herança teria passado, meio pelo meio, aos ascendentes do morto. Ato continuo, a morte dos ascendentes faria transinitir o acervo recebido aos descendentes de cada qual. Assim, o irmão bilateral receberia uma quota de seu pai, outra de sua mãe, ao passo que o irmão unilateral receberia uma única quota, advinda ou de seu pai ou de sua mãe.

Entretanto tal ficção não é levada a extremos, motivo pelo qual. se concorrerem apenas irmãos unilaterais, cada um deles recebc uma quota equivalente, cessando a presunção de que os genitores do de cujus teriam herdado antes dos irmãos deste (art. I.842, CCB/2002).

O caput do art. $1.843 \mathrm{CCB} / 2002$, por sua vez, determina que não havendo irmãos sucessiveis, herdarão os sobrinhos do morto, parentes colaterais em terceiro grau. 
e, apenas na falta dos sobrinhos, serão chamados a suceder os tios do falecido, também eles parentes colaterais de terceiro grau, mas que são preteridos cm razão de que amor primum descendit, deinde ascendit.

Us parágrafos do art. $1.843 \mathrm{CCB} / 2002$ traçam regras para a verificação da forma de partilhar semelhantes àquelas regras baseadas na bilateralidade ou unilateralidade dos irmãos e na conseqüente forma de partilhar proporcionalmente o montante partivel da herança.

Apenas na falta de parentes sucessíveis de terceiro grau é que serão chamados os colaterais de quarto grau. Todavia, a lei não traça regras para convocação dos parentes de quarto grau, fazendo com que o intérprete seja forçado a concluir pelo chamamento simultâneo de todos os primos, tios-avós e sobrinhos-netos do falecido, uma vez que estes sejam os colaterais de quarto grau.

Por fim, na ausência de quaisquer parentes sucessíveis o companheiro sobrevivente poderá amealhar a totalidade dos bens adquiridos onerosamente durante a vigência da união estável, segundo o que determinam o inc. IV e o caput do art. 1.790 CC.B/2002. Assim, quanto aos bens particulares do falecido, inexistindo parentes sucessiveis, serão os mesmos entregues ao Poder Público. em detrimento do companheiro supérstite.

2.3. A sucessão do viúvo, do solteiro. do divorciado e do separado judicialmente ou do separado de fato a mais de dois anos

Quando a pessoa que falece ostentava o estado civil de viúvo, solteiro não unido estavelmente com outra pessoa. era divorciada ou separada judicialmente ou quando era separada de fato a mais de dois anos. podendo a culpa ser atribuída de forma exclusiva ou mesmo concorrente ao cônjuge sobrevivo, ocasiões em yue será afastada da sucessão por força do disposto no art. $1.830 \mathrm{CCB} / 2002$.

Nestes casos, a sucessão se inicia com a convocação de eventuais descendentes do falecido, os de graus mais próximo afastando os de grau mais remoto, dividindo-se o monte partivel em tantas partes iguais quantos forem os descendentes de mesmo grau, ressalvado o direito de representação.

$\mathrm{Na}$ falta de descendentes serão chamados a suceder os ascendentes, vedado o direito de representação, com os ascendentes de grau mais próximo excluindo os de grau mais remoto. $\mathrm{Na}$ falta de um dos pais do falecido. o outro amealhará. sozinho, todo o acervo hereditário.

Outra hipótese possivel é a de que ambos os genitores tenham pré-morrido 
ao filho, ora autor da herança. Neste caso, com a falta de ascendentes de primeiro grau do falecido, serão convocadas para a sucessão as linhas ascendentes de segundo grau, ou seja, os avós matcrnos c os avós paternos. Supondo-se quc os quatro avós sejam vivos, a eles tocará a divisão da totalidade do acervo, quando cada um dos avós receberá uma quarta parte da totalidade da hurança.

Se, todavia. apenas um dos avós tiver condições de representar uma das linhas e se na outra linha ambos os avós puderem representá-la na sucessão, cada uma das linhas receberá metade do acervo hereditário. Na linha onde apenas um dos avós é vivo, este receberá a metade da herança. Na outra linha, por sua vez, a cada avô será entregue uma quarta parte do monte.

Em um outro cenário. quando houver um avô em cada linha, cada metade da herança será entregue a cada linha. sem necessidade de se proceder a outra divisão, na exata medida em que haja apenas um avô paterno e outro materno.

Se houver representantes em apenas uma das linhas, por outro lado, a herança surá deferida à linha representada, subdividindo-se o acervo entre o avô e a avó, cabendo a cada um deles metade do monte partível. Por fim, se houver apenas um dos avós em condição de herdar, este amealhará a totalidade da herança.

$\mathrm{Na}$ falta de descendentes e de ascendentes a herança será partilhada entre os colaterais até o yuarto grau segundo as regras dos arts. 1.839 a 1.843 , todos do CCB/2002.

Nesta última classe chamada a herdar, os parentes colaterais de grau mais próximo excluem os de grau mais remoto. admitida a representação dos irmãos do falecido que tiverem pré-morrido a este, pelos sobrinhos do defunto, segundo o que dispõe o art. 1840 CCB/2002.

A partir daqui, a sucessão das pessoas abarcadas por este tópico seguem a mesma lógica e as mesmas regras verificadas no itum anterior, mas com a particular situação de que os herdeiros colaterais dividirão, segundo estas regras. a totalidade do acervo.

3. O sistema complexo de vocação hereditária criado pelo código civil italiano, dependente das relações familiais

Dizur que o Código Civil italiano encerre uma ordem de vocação hereditária é uma afirmação verdadeira na medida em que su entenda por esta expressão a ordem de chamamento dos sucessivicis para aceitar ou recusar a herança. uma vez que o legislador italiano preveja a aceitação, como condição indispensável para a aquisição da herança que houvera sofrido delação com a abertura da sucessão (arts. 457 e 459 CCI). $\dot{E}$ que como 
afirma Orlando Gomes, a atribuição dos direitos aos sucessores traduz-se pelo vocábulo devolução ${ }^{15}$ ou delação, que nada mais representam do que o mesmo fenômeno (abertura da succssão), só que, agora, visto pelo prisma da succssibilidadc. ${ }^{16}$

Mas se é verdade que haja uma ordem de vocação hereditária no sistema jurídico italiano, também é verdade que ela não se encontra solidificada em um ou alguns dos dispositivos do livro segundo daquele Código Civil, exatamente o extrato daquela codificação que cuida de regular a transmissão dos bens da pessoa que falece a seus sucessores. Ao contrário, para que se possa atingir a intenção do legislador de 1942, faz-se necessário um verdadeiro excrcício de exegese de todo um título daquele corpo legislativo, mais especificamente do título II.

Com efeito, a forma pela qual o legislador italiano houve por bem estruturar o chamamento dos sucessiveis legitimos haseou-se na divisão deste chamamento cm três capítulos distintos e segundo regras casuísticas que lhe pareceram as mais relevantes. ${ }^{17}$

Em um primeiro momento, o CCI faz referência a sucessão dos parentes. trazendo então, dos arts. 566 a 580, uma série de hipóteses para o endereçamento dos bens que não podem restar acéfalos, hipóteses estas que, no mais das vezes, se interpenetram e acabam por se mostrar dependentes dos dispositivos seguintes.

Em um segundo momento de sua técnica legislativa, o $\mathrm{CCl}$ faz refurincia à sucessão do cônjuge, sem que isso possa representar um menoscabo da posição do sobrevivo, como pode parecer numa primeira abordagem. Ao contrário, o que este capítulo II faz é traçar regras atinentes ao concurso do cônjuge sobrevivente relativamente aus demais sucessíveis, quais sejam os parentes mencionados e hierarquizados no capítulo precedente.

Por fim, no terceiro momento de considerações a respeito da sucessão legitima, o legislador italiano faz referência ao Estado, afirmando tratar-se de hipótese de devolução, ao Estado, dos bens da herança, quando aquele adquire o patrimônio vago, sem necessidade de aceitação e sem qualquer hipótese de renúncia por sua parte, como já se afirmou acima.

Diante desta multiplicidade de regras, tentar-se-á proceder a uma mínima sistematização dos aspectos relacionados com a ordem de vocação hereditária,

is SANTOS, J. M. Carvalho. Código Civil Interpretado: direito das sucessões. v. 22, p. 7.

16 GOMES, Orlando. Sucessões. 11. ed. Rio de Janeiro: Forense, 2001. p. 11.

17 Da mesma forma agiu o legislador italiano ao prever a porção do patrimônio do falecido que restaria indisponivel pela existência de herdeiros necessurios. Assim é que dos ans. 536 a 552, o CCl vai estabelecendo os valores da parte indisponivel conforme existam entre os herdeiros, sucessores das mais diversas categorias, segundo o seu grau de parentesco, a sua relação familial, bem como a quantidade de cada um dos sucessiveis considerados. 
aproximando-se, tanto quanto possível, de seu estabelecimento claro e inequívoco. Este lavor, todavia, não tem outra intenção que não a de dar a conhecer a sistemática italiana, sem que se tenha, em qualquer momento, a intenção de comparar os sistemas. É o que se procurará esboçar nos sub-itens seguintes.

A partir deste momento, então, os títulos chamam a atenção para a hipótese de coexistirem todos os sucessiveis imaginados pelo legislador italiano para amcalhar fração ideal segundo os critćrios que determina e que serão explicitados. Pode bem ser, portanto, que faltem alguns ou pelo menos algum dos concorrentes indicados no título. Esta circunstância, no entanto, não ilide a previsão legal, uma vez que o que o legislador italiano fez foi prever, primordialmente, a coexistência referida no título. Assim, ainda que haja falta de um dos sucessíveis, será necessário, ao menos, perquirir a respeito de sua existência uu de sua disponibilidade para assumir a quota que se the delatou.

\subsection{Vocação concorrente de descendentes e cônjuge}

A primuira ordem de vocação hereditária, assim, prevê o chamamento dos descendentes e do cônjuge do falecido para receberem uma parcela mais ou menos variável do monte-mor.

Em relação ao cônjuge, a legislação italiana é bem clara ao dispor que sucederá o cônjuge não separado, assim como o cônjuge separado que não tiver obrado com culpa para a separação, além de prever a participação do cônjuge culpado, sempre que a culpa pela separação for concorrente, ou seja. sempre que a separação tiver tido lugar por culpa tanto dele, sobrevivente, como do morto (art. 585 combinado com o art. 548, (CI). Na hipótese de haver cônjuge putativo, este participará da sucessão sempre tiver agido de boa-fí e o casamento tiver sido declarado nulo após a abertura da sucessão, herdando como se cônjuge de casamento válido fosse.

Determina o art. $581 \mathrm{CCI}$ que se o cônjuge concorrer com um único filho, seja ele legítimo ou natural, amealhará metade dos bens da herança, deixados pelo falecido. Se, todavia, concorrer com mais de um filho, quer sejam eles descentes legítimos, naturais ou de ambas as origens, ser-lhe-á resguardada a terça parte dos bens do morto, dividindo-se os dois terços restantes entre os filhos existentes, sejam eles legítimos ou naturais. sem distinção. Esta disposição está matematicamente de acordo com a reserva da parte indisponível prevista no art. 542, CC] que manda reservar metade do patrimônio do morto aos filhos e um quarto daquele patrimônio ao cônjuge. Ora, metade mais um quarto são trìs quartos. Estes três quartos correspondem a um inteiro da parte indisponivel que, quando dividida, terá um terço reservado ao cônjuge. Este terço da parte indisponível 
é um lerço dos três quartos do total do patrimônio, ou seja, o cônjuge receberá exatamente um quarto do total do patrimônio, que i a sua reserva legitimaria!

No entanto, a leitura isolada do art. 581, citado, pode indicar ao intérprete a impressão de lacuna legislativa relativamente à comum hipótesc de existirem filhos legitimados ou adotivos, em situação de concorrência com o cônjuge. Dai por que se faça necessária a leitura atenta dos vários artigos deste Titulo II, como já se fez referência. Isto porque a equiparação legal dos filhos legitimados e dos adotivos aos filhos legítimos está determinada no art. $567 \mathrm{CCI}$.

Assim, reservar-se-á a metade ou a terça parte dos bens da herança, conformc o caso, sempre que o cônjuge sobrevivente concorrer com filhos legitimos, legitimados, adotivos ou naturais. O restante da herança scrá atribuido, então, aos filhos existentes, em partes iguais, segundo o que determina o art. $566 \mathrm{CCI}$, com a expressa remissão que faz ao art. 537 do mesmo Código, o qual determina a possibilidade de que os filhos legítimos (e, portanto, também os legitimados e os adotivos, posto que a eles equiparados) satisfaçam o montante cabivel aos filhos naturais em dinheiro ou em bens imóveis existentes no monte-mor, desde que a isto não se oponham os sucessores naturais. Se, todavia. e por qualquer razão, os herdeiros naturais se opuserem. caberá ao juiz determinar a forma de divisão. levando em conta, por expressa determinação legal, as circunstâncias pessoais e patrimoniais dos filhos envolvidos na pendenga.

$\mathrm{O}$ art. $573 \mathrm{CCI}$ alirma, por sua vez, que os filhos naturais com direito a participar das relações sucessórias são aqueles cuja filiação fora reconhecida pelo falecido ou ainda aqueles que tiverem assistido o estabelecimento da relação paterno/materno-filial por meio de declaração judicial. Os filhos naturais não-reconhecidos, no entanto, não restam totalmente alijados. Se é verdade que não participarão da sucessão, amcalhando parte do acervo hereditário, tamhém é verdade que tcrão direito a uma espécie de pensão vitalícia calculada com base nos frutos e rendimentos produzidos pela parte que lhes tocaria na herança, caso tivessem sido reconhecidos. Esta regra vem estabelecida no art. $580 \mathrm{CCl}$ e visa prover assistencialmente aqueles fillhos que não tiveraı o estabelecimento de sua patemidade e/ou maternidade confirmados.

O Direito italiano conhece o direito de representação nos mesmos moldes ım que estabelecido no direito brasileiro desde o tempo de vigîncia do $C C B / 1916$. Havia, no entanto, uma limitação relativamente ao direito de representação exercido por fillhos naturais quando em lugar de seus genitores, e sempre que estes fossem genitores legítimos do autor da herança. Nesta hipótese, o art. $577 \mathrm{CCl}$ limitava a representação apenas na hipótese de não existirem cônjuge, descendentes, ascendentes ou colaterais até o terceiro grau do autor da herança. Este artigo teve 
aplicação até 1969, quando a Corte Constitucional Italiana o declarou ilegítimo por meio da Sentença n. 79 de 14 de abril.

Dúvida paira, no que concerne a primeira ordem de vocação hereditária, relativamente a eventual participação dos irmãos e irmãs do falecido nesta primeira ordem. uma vez que o art. 568 CCI inicie a vocação da segunda ordem afirmando que os pais do morto sucedem sempre que ele não tiver deixado prole, nem irmãos e irmãs ou seus descendentes, por direito de representação. Entretanto, não há, no Título segundo sob análise, qualquer regra que determine quer a concorrência entre os colaterais de segundo grau com os fillhos c o cônjuge do falecido, nem há sequer uma mísera menção à forma de se partilhar o monte-mor, nesta hipótese aqui aventada, tornando impossível proceder a esta divisão.

Em suma, pode-se afirmar que a primeira ordem de vocação hereditária no sistema juridico privado italiano convoca para o recebimento da herança os filhos do morto (legítimos, legitimados, adotivos e naturais reconhecidos ou declarados judicialmente), todos em igualdades de condições e amealhando o mesmo percentual, resguardada uma certa parte ao cônjuge sobrevivente sempre que ele concorra com um único filho ou com mais de um filho, hipóteses em que ter-lhe-á sido resguardada metade ou um terço da hurança, respectivamente.

Se, todavia, não houver cônjuge sobrevivente, a totalidade do acervo será dividida entre os fillhos do de cujus.

\subsection{Vocação concorrente dos genitores, cônjugı e irmãos}

Se o falecido não tiver deixado filhos ou mesmo netos do autor da herança que representassem seus pais pré-mortos, serão chamados a suceder os genitores do falecido, scegundo o que dispõe o art. $568 \mathrm{CCl}$, fazendo recair ao pai e à mãe do falecido os mesmos direitos relativamente à herança, ou seja, deferindo a cada qual uma quota idêntica àquela atribuída ao outro.

$\dot{E}$ interessante notar que o legislador separa a hipótuse da sucessão recair sobre os genitores, daquela outra hipótese em que devam ser chamados a herdar os ascendentes mais remotos do falecido, como seus avós, por exemplo. Esta diferenciação pode sur sentida tanto nos arts. 568 e $569 \mathrm{CCl}$, como no art. 571 do mesmo diploma legislativo, quando se prevê a hipótese de concorrência de inmãos ou irmãs do lalecido com os genitores ou com os ascendentes mais remotos do autor da herança. Pode-se afirmar, sem medo de errar, que a distinção operada pelo legislador civil italiano de 1942 no capítulo I deste Título que se analisa tem uma clara razão de ser: tratava-se de 
disciplinar, então, a sucessão pelos parentes. E quando a vocação atingia os parentes, de forma indistinta, o legislador escolheu privilegiar os pais do autor da herança em detrimento de seus avós, os quais só serão chamados à falta dos pais do morto. Por outras palavras, o que tez o legislador italiano, separando os graus de parentes em linha reta ascendente foi proibir, por via pouco técnica, é verdade, o direito de representação em favor dos avós do morto, quando lhe faltasse um dos genitores. As conseqüências práticas, então, mostram-se absolutamente idênticas às que ocorrem no Brasil, onde o legislador deixou bem assentada a impossibilidade de se recorrer ao direito de representação quando se tratasse de linha reta ascendente.

Da mesma forma, a distinção é sentida quando se coteja os arts. $579 \mathrm{CCl}$. relativo à concorrência do cônjuge com os genitores do morto, e o art. 582 do mesmo diploma. É possível claramente perceber a constante e crescente preocupação do legislador com a proteção do viúvo ou da viúva, acrescentando-lhe direitos sucessórios à midida que cresce a sua vocação. Assim, quando a sucessão passa a ser règulada em razão do vinculo matrimonial (c não mais em razão do parentesco, como ocorria no Título I), os parentes $\mathrm{cm}$ linha reta ascendente passam a ser tratados, todos, como ascendentes, sempre que o vínculo que guardavam com o falecido fosse um vínculo legítimo, o que explica a redação do art. 579 que se refere primordialmente ao caso de filhos naturais reconhecidos pelos genitores-herdeiros. Em ambos os casos a solução legislativa é idêntica, comprovando mais uma vez que os fillos legítimos e os naturais. além dos a eles equiparados (legitimados e adotivos) dispõem de mesma proteção legal.

Para se saber quais sejam as quotas atribuiveis a cada um dos genitores e dos demais concorrentes faz-se mister recorrer aos artigos que prevêem tanto a concorrência do cônjuge sobrevivo e com direito à herança (veja-se o subitem 3.1, supra), como a concorrência eventual de irmãos ou irmãs do falecido, que amealharão uma parte do patrimônio disponívil.

Assim, nos art. 582 e 579 CCl o legislador garante an cônjuge sobrevivente a devolução de dois terços da herança sempre que este concorrer com os ascendentes legítimos ou naturais do autor da herança. prevendo, ainda, que esta quantia será fixa, mesmo que os irmãos e irmãs do falecido sejam chamados a herdar. Também estas disposições estão matematicamente de acordo com a reserva da parte indisponível prevista no art. 544, CCl que manda reservar metade do patrimônio do morto ao cônjuge sobrevivo e um quarto daquele patrimônio aos ascendentes. Ora, como já se comprovou acima, metade mais um quarto são três quartos. Estes três quartos correspondem a um inteiro da parte indisponível que, quando dividida, terá um terço reservado aos ascendentes. Este terço da parte indisponível é um terço dos três quartos do total do patrimônio, ou seja, os 
ascendentes dividirão entre si exatamente um quarto do total do patrimônio, que é a reserva legitimaria que a lei lhes garante!

A terça parte restante, então, será repartida entre os genitores do falecido c entre seus eventuais irnãos e irmãs segundo as regras dos arts. 568 e 571 CCI.

Supondo a inexistência de irmãos e irmãs, bem como de filhos que os pudessem representar, a terça parte restante seria dividida entre ambos os genitores do morto, amealhando cada yual uma sexta parte do patrimônio não abarcado em eventual testamento. Se, todavia, apenas um dos genitores aderisse à herança ou fosse sobrevivo ao filho recém morto, este amealharia, sozinho, a terça parte do acervo.

A forma de divisão se complica tanto mais quanto mais são os envolvidos que atendam à vocação operada pela lei. Assim, se além do cônjuge sobruvivo e do(s) genitor(es) concorrerem também os irmãos ¿/ou irmãs do falecido, socorrer-se-á o intérprete do art. 57I CCI. Nesta hipótese, dois terços da herança permanecem sendo atribuídos ao cônjuge sobrevivente, ao passo que a divisão da terça parte restante será feita tomando-se o número de genitores sobreviventes e somando-se a eles o número de iımãos ou irmăs germanos ou bilaterais, os quais concorrerão por cabeça. Se. todavia, a concorrência se der também entre irmãos unilaterais do falecido, estes receberão a metade da quota atribuída a cada um dos genitores ou dos irmãos germanos. Para a composição prática desta divisão, então. os genitores e os irmãos germanos são contados como 2 e cada um dos unilaterais é contado como uma única porção, dividindosc a terça parte restante entre eles e atribuindo-se o resultado obtido a cada um dos irmãos c irmãs unilaterais e duas vezus aquele valor a cada um dos genitores e irmãos e irmãs bilaterais.

Assim, na hipótese de haver ambos os genitores e um irmão germano, este receberá um nono do acervo, cabendo a mesma quantia ao pai e outro tanto à mãe do morto. Se todavia, se tratar de um irmão unilateral este receberá um quinze avos do acervo e cada um dos genitores do falecido amealhará dois quinze avos do acervo. o que perfaz cinco quinze avos do monte-mor, ou seja, uma terça parte do acervo.

Por outro lado, na hipótese de haver um único genitor e três irmãos germanos, estes receberão um doze avos do acervo, cabendo a mesma quantia ao genitor sobrevivo perfazendo quatro doze avos, ou seja, um terço da herança. Se todavia, se tratar de três irmãos unilaterais estes receberão um quinze avos do acervo cada e o genitor que tiver sobrevivido ao falecido amcalhará dois quinze avos do acervo, o que perfaz cinco quinze avos do monte-mor, ou suja, uma terça parte da herança. No entanto, se dois dos irmãos Cossem germanos e um deles fosse unilateral, essa musma divisão acarretaria um vinte e um avos ao irmão unilateral e dois vinte e um avos a 
cada um dos dois irmãos germanos e outra quantia idêntica ao genitor sobrevivente, o que totalizaria a fração de sete vinte e um avos, ou seja, um terço do acervo hereditário.

Se, todavia, não houver cônjuge sobrevivente, a totalidade do acervo será dividida entre os pais e os irmãos do de cujus, segundo as regras por último analisadas.

\subsection{Vocação concorrente dos demais ascendentes, cônjuge e irmãos}

Inexistindo descendentes e genitores, serão chamados a suceder os ascendentes a partir do segundo grau, conforme a determinação do art. $569 \mathrm{CCI}$, fazendo a lei referência, ainda, à concorrência do cônjuge e dos irmãos do falecido.

Assim, e segundo as regras explicitadas no sub-item anterior, o cônjuge sobrevivente eventualmente existente amealhará dois terços do monte-mor, fazendo com que o terço seguinte seja dividido entre os ascendentes do falecido que não sejam os scus pais, pré-mortos os quais dividirão a terça parte que lhes cabe com os eventuais irmãos e irmãs do falecido.

Supondo que apenas os ascendentes concorram com o cônjuge sobrevivente, a terça parte que toca aos primeiros será dividida em duas partes iguais equivalentes à sexta parte do acervo total, sendo uma sexta parte entregue à linha paterna e outra sexta parte entregue à linha materna, se ambos os ascendentes guardarem o mesmo grau de parentesco relativamente ao autor da herança.

Assim, o chamamento dos ascendentes iniciar-se-á pelos ascendentes de grau mais próximo, posto que estes excluam os de grau mais remoto. Neste sentido, os primeiros a serem convocados para adir à herança são os avós do de cujus, em concorrência com o cônjuge supérstite.

Neste caso, serão conrocadas para a sucessão as linhas ascendentes de segundo grau, ou seja, os avós maternos e os avós paternos. Supondo-se que os quatro avós sejam vivos, a eles tocará a divisão da terça parte do acervo, quando cada um dos avós receberá um doze avos da totalidade da herança que, somadas, perfarão quatro doze avos, equivalentes a terça parte do acervo.

Se. todavia, apenas um dos avós tiver condições de representar uma das linhas e se na outra linha ambos os avós puderem representá-la na sucessão, cada uma das linhas receberá um sexto do acervo hureditário, tocando o restante ao cônjuge sobrevivo. $\mathrm{Na}$ linha onde apenas um dos avós é vivo, este receberá a sexta parte da herança. Na outra linha, por sua vez, a cada avô será entregue um doze avos do monte.

Em um outro cenário, quando houver um avô em cada linha, a herança 
atribuida ao cônjuge sobrevivente permanece invariável. sendo-lhe deferidos dois terços do acervo e a terça parte remanescente será partilhada entre as duas linhas, cabundo um sexto da herança a cada uma delas, sem necessidade de se proceder a outra divisão, na exata medida em que haja apenas um avô paterno e outro materno.

Se houver representantes em apınas uma das linhas, por outro lado, dois terços da herança serão ıntregues ao cônjuge sobrevivente é um terço surá deferido à linha representada, subdividindo-se esta parte do acervo entre o avô e a avó, cabendo a cada um deles um sexto do monte partivel. Por fim, se houver apenas um dos avós em condição de herdar, este amealhará o terço da herança que não tiver sido entregue ao cônjuge sobrevivente.

A parte final do art. 571 C.C.I. por sua vez, abre brecha à proibição de que os ascendentes mais remotos representem os ascendentes mais próximos ao morto, sempre que se tiver de proceder à concorrência entre os avós e os irmãos do morto, por exemplo. Com efeito, afirma o art. 571, em sua parte final que "se, no entanto, os gunitores não puderem ou não quiserem participar da sucessão, e existirem ulteriores ascendentes, a estes últimos se devolve, do modo determinado no art. 569, a quota que seria destinada a um dos genitores à falta do outro" (tradução livre).

t.m uma primeira aproximação este excerto legal poderia sugerir que a devolução ocorresse exclusivamente do modo determinado no art. 569 CCI, fazendo com que se afastasse a concorrência dos irmãos e irmãs do de cujus. Todavia. não pode ser esta a exegese a prevalecer, uma vez que o art. 571 trate exatamente da hipótese de concorrência dos genitores ou ascendentes com os irmãos e irmãs du falecido.

Bem por isso, em havendo avós, cônjuge e irmãos ou immãs, parece que a divisão deva ser feita segundo o que dispõe o art. 571, quando considera a presença dos genitores do falecido, com a única ressalva de que, em razão da remissão ao art. 569, esla divisão considerará presentes no chamamento sucessório não mais cada um dos genitores, mas levará em consideração a existência de avós em cada uma das linhas envolvidas. $\mathrm{Na}$ falta de avós, então, passaria a considerar eventuais bisavós e assim sucessivamente, já que "se os ascendentes não são de igual grau. a herança é devolvida ao mais próximo. sem distinção de linha"

A forma de divisão se complica tanto mais quanto mais são os envolvidos que atendam à vocação operada pela lei. Assim, se além do cônjuge sobrevivo e do(s) ascendente(es) concorrerem também os irmãos e/ou irmãs do falecido, socorrer-se-á o intérprete do art. 571 CC.I. Nesta hipótese. dois terços da herança permanecem sendo atribuidos ao cônjuge sobrevivente, ao passu que a divisão da terça parte restante será fiita tomando-sc o número de linhas com representantes em mesmo grau de parentesco 
(ou seja, o número de linhas com avós, por exemplo) e somando-se a estas o número de irmãos ou irmãs germanos ou bilaterais, os quais concorrerão por cabeça. Se, todavia, a concorrência sc der também entre irmāos unilaterais do falecido, estes receberão a mitade da quota atribuida a cada uma das linhas ou dos irmãos germanos. Para a composição prática desta divisão, então, as linhas e os irmãos germanos são contados como 2 e cada um dos unilaterais é contado como uma única porção, dividindo-se a terça parte restante entre eles e atribuindo-se o resultado obtido a cada um dos irmãos e irmãs unilaterais e duas vezes aquele valor a cada uma das linhas e irmãos e irmãs bilaterais.

Operada esta divisão entre as linhas e os irmãos segundo sua própria condição, haverá a necessidade de se verificar se o quantum atribuído a cada uma das linhas necessita ou-não sofrer nova divisão. Será necessário se proceder a esta divisão sempre que houver mais de um avô ou bisavô (conforme o grau dos ascendentes convocados) na linha materna ou na linha paterna.

Assim, na hipótese de haver representantes em ambas as linhas e um irmão germano, este receberá um nono do acervo, cabendo a mesma quantia à linha patcrna e outro tanto à linha materna da qual descendia o morto, procedendo-se ou-não a uma nova divisão que agraciará os herdeiros ascendentes abarcados em cada uma das linhas. Se, todavia, se tratar de um irmão unilateral este receberá um quinze avos do acervo e cada uma das linhas de ascendência do falecido amealhará dois quinze avos do acervo, o que perfaz cinco quinze avos do monte-mor, ou seja, uma terça parte do acervo, verificando-se a necessidade ou não da nova divisão do acervo.

Por outro lado, na hipótese de haver uma única linha representada e quatro irmãos germanos, estes receberão um quinze avos do acervo, cabendo a mesma quantia à linha representada perfazendo cinco quinze avos, ou seja, um terço da herança. Aquela décima quinta parte entregue à linha representada poderá ou-não sofrer nova divisão, conforme seja o caso de existir apenas um ou ambos os avós. Se todavia, se tratar de três irmãos unilaterais estes reccberão um quinze avos do acervo cada e a linha que tiver representantes vivos amealhará dois quinze avos do acervo, o que perfaz cinco quinze avos do monte-mor, ou seja, uma terça parte da herança. No entanto. se dois dos irmãos fossem germanos e um deles fosse unilateral, essa mesma divisão acarretaria um vinte e um avos ao irmão unilateral e dois vinte e um avos a cada um dos dois irmãos germanos e outra quantia idêntica à linha com representantes, o que totalizaria a fração de sete vinte e um avos, ou seja. um terço do acervo hereditário.

Se, todavia, não houver cônjuge sobrevivente, a tolalidade do acervo será dividida entre os ascendentes e os irmãos do de cujus, segundo as regras aqui analisadas. 


\subsection{Vocação concorrente do cônjuge e dos irmãos}

Quando o falccido for filho natural reconhecido por aperas um dos genitores, o art. 578 CCI determina que de sua sucessão só participará o genitor que lhe tiver reconhecido, afirmando peremptoriamente que o outro será excluido da sucessão.

Assim, no Direito italiano não é apenas a sucessão dos falecidos sem prole e sem ascendentes que será deferida ao cônjuge sobrevivente. Com efeito, também a sucessão daquele que tivesse um genitor que não the reconhecera como filho será deferida ao cônjuge, em terceira ordem de vocação hereditária, em concorrência com os irmãos e irmãs do falecido. Afirma-se isto nesta sede para se deixar bem clara a intenção subjacente ao legislador italiano quando tratou de forjar o art. 578 CCI, em nítida contraposição à regra do art. 579 do mesmo código, artigo este, relembre-se, que garante assistência ao filho não-reconhecido, que passará a gozar de uma perpétua renda em seu favor, calculada com base no montante do acervo que the caberia, caso tivesse sido reconhecido por seu genitor. Aqui, ao revés, nenhuma assistência, nenhum consolo, nenhuma forma de benefício. Exclusão pura e simples daquele que podendo ter assumido como seu o filho que gerara, não o fez, tenha ou-não tido razões para tanto, fossem quais fossem as razões existentes neste sentido.

Em verdade, se o Direito italiano mantém a classificação da descendência segundo a sua origem, fato é que não tem gerado qualquer diminuição de direitos entre os vários filhos, ao menos no campo sucessório. Com efeito, a legislação sucessória italiana afirma a equivalência entre os filhos legitimos, legitimados, naturais e adotivos, muito embora restrinja relativamente a estes últimos as relações sucessórias, fazendo-as incidir apenas entre pais e fillhos adotivos. E ao afirmar esta equivalência garante-lhes, na condição de fillhos (já não assim na de netos, irmãos etc.) os mesmo dircitos. E vai além! Pois garante ao filho natural não-reconhecido, nem como tal declarado por intervenção judicial, a condição de merecedor de uma assistência perpétua, mesmo que este não tenha jamais a possibilidade de constituir a paternidade que lhe fora negada.

Mas, retornando ao objeto central deste estudo, convém agora tecer considerações a respeito da forma de se partilhar a herança daquele que tenha falecido sem deixar descendentes, nem ascendentes conhecidos.

A lei convoca, neste caso, o cônjuge do autor da herança para que este amealhe dois terços da herança (art. 582, CCI), resguardando a terça parte restante para ser partilhada pelos irmãos e irmãs do falecido, segundo as regras estabelecidas no art. $570 \mathrm{CCl}$, garantindo-se, ainda, a representação dos filhos dos irmãos pré-mortos, em qualquer hipótese. 
Assim, os irmãos e irmãs concorrerão entre si pela divisão desta terça parte do acervo amealhando uma parte ou meia parte scgundo sua condição relativamente ao morto fosse a de irmão germano ou unilateral.

Irmãos, como já se afirmou acima, são os parentes colaterais de segundo grau que têm em comum ao menos um genitor. Quando apenas o pai é comum, dizem-se irmãos unilaterais consangïineos, ao passo que se apenas a mãe é comum, dizem-se irmãos unilaterais uterinos. Por outro lado, se ambos os genitores são comuns, os irmãos nestas condições são ditos bilaterais ou germanos.

A distinção i importante, em termos sucessórios, uma vez que a lei italiana restringe a quota parte cabível aos irmãos unilaterais à metade da quota recebida pelos irmãos germanos. Essa restrição. percebe-se, não leva em consideração os irmãos em si. mas sim a relação do de cujus com os pais do herdeiro.

A lei entende que scria injusto que um irmão unilateral recebesse a mesma quantia que é entregue a um irmão bilateral e isto pode ser explicado por uma ficção que estaria implícita no raciocínio legal. Segundo esta ficção, como já se expôs, a herança teria passado, meio pelo meio, aos ascendentes do morto. Ato contínuo. a morte dos ascendentes faria transmitir o acervo recebido aos descendentes de cada qual. Assim, o irmão bilateral receberia uma quota de seu pai, outra de sua mãe, ao passo que o irmão unilateral receberia uma única quota, advinda ou de seu pai ou de sua mãe.

Entretanto, tal ficção não é levada a extremos, motivo pelo qual, se concorrerem apenas irmãos unilaterais (ausentes os genitores, os demais ascendentes e os irmãos germanos como se viu), cada um deles reccbe uma quota equivalente, cessando a presunção de que os genitores do de cujus teriam herdado antes dos irmãos deste.

Assim, e mais uma vez em razão da divisão prática do acervo, cada um dos irmãos germanos é contado como se fosse 2 e cada um dos unilaterais é contado individualmente, dividindo-se a terça parte da herança pelo número que resultar da soma do número de irmãos germanos multiplicado por dois e o número de irmãos unilaterais. Assim: terça parte/ $(2 \mathrm{~g}+\mathrm{u})$. Obtido o valor desta operação matemática, esta será a quota cabível a cada um dos herdeiros unilaterais e o seu dobro será o valor da quota atribuível aos irmãos germanos.

Se, todavia, não houver cônjuge sobrevivente, a totalidade do acervo será dividida entre os irmãos do de cujus, segundo as regras aqui discutidas.

\subsection{Vocação do cônjuge}

Não havendo descendentes, ascendentes de qualquer grau, nem parentes colaterais de segundo grau, ou seja, irmãos, o cônjuge sobrevivente receberá a totalidade do acervo hereditário. 
Assim como em cualquer das outras situações em que é concorrente, o cônjuge só herdará se comprovar que estava casado com o autor da herança no momento da morte deste ou, se separado. se conseguir demonstrar que a separação se deu por culpa do autor da herança, culpa esta que poderá ter sido exclusiva do falecido ou mesmo concorrente, vale dizer, se tiver existido culpa de ambos os membros do casal na ruptura da vida em comum. Nesta hipótese, o legislador italiano não considera justo alijar da sucessão o cônjuge separado, ainda que este tenha sido co-responsável pela separação. Trata-se de uma tentativa de não escalonar as culpas, tornando objetivamente desnecessária qualquer forma de discussão no sentido de se tentar provar que. nãoobstante a culpa do sobrevivo, sobreviera culpa do falecido, reabrindo-se uma discussão desnecessária e pouco proveitosa.

\subsection{Vocação dos demais parentes colaterais}

Por fim, na ausência de qualquer dos anteriormente convocados a herdar serão chamados a adir à herança os demais parentes existentes, até o sexto grau, sem qualquer distinção de linha, segundo a afirmação do art. 572 CCl.

Diferentemente do que ocorre no Direito brasileiro, o legislador italiano não previu qualquer forma de escalonamento entre os parentes colaterais sucessíveis que não os irmãos e os sobrinhos do morto (posto que os sobrinhos possam ter representado seus pais pré-mortos, inclusivamente se todos os irmãos do morto fossem pré-mortos, conforme se pode depreender do art. 469 CCI, quando este afirma que a representação tem lugar inclusive quando há unicidade de estirpe).

Assim, todos os parentes colaterais até o sexto grau serão chamados a herdar, em igualdade de condições. Saliente-se que segundo a dicção dos arts. 76 e $77 \mathrm{CCI}$ a contagem de graus de parentesco se faz por forma idêntica a que se emprega no Brasil. Todavia, no Direito italiano o parentesco se estende até o sexto-grau, sendo certo que o Dircito brasileiro limita o parentesco até o quarto grau.

São Paulo. dezembro de 2005.

Referências

CAHALI, Francisco José; HIRONAKA, Giselda Maria lemandes Novaes. ('urso Avançudo de Direito Civil. 2. ed. São Paulo: Revista dos Tribunais, 2003. v. 6. 
DINIZ, Maria Helena. Curso de Direito Civil Brasileiro: Direito das Sucessões. 13. ed. São Paulo: Saraiva, 1999. v. 6.

GOMES, Orlando. Sucessões. 11 ed. Rio de Janeiro: Forense, 2001.

HIRUNAKA, Gisclda Maria Femandes Novaes. Comentários ao Código Civil. Coord. Antônio Junqueira de Azevedo. São Paulo: Saraiva, 2003. เ. 20

Concorrência do companheiro e do cônjuge na sucessão dos descendentes. In: DELGADO. Maria Luiz; ALVES. Jones Figueiredo. (Coords.). Questões Controvertidas no Vovo Código Civil. São Paulo: Ed. Método, 2003.

MAXIMilian(), Carlos. Direito das Sucessões. São Paulo: Freitas Bastos, 1964. v. 1.

MONTEIRO, Washington de Barros. Curso de Direito Civil: Direito das Sucessões. 33. ed. São Paulo: Saraiva, 1999. v. 6.

MORAES, Walter. Programa de Direito das Sucessões: Tcoria Geral c Sucessão Legítima. 2. cd. São Paulo: Revista dos Tribunais. 1980.

OLIVEIRA, Arthur Vasco Itabaiana de. Tratado de Direito das Sucessões. São Paulo: Max Limonad, 1952. v. 1.

PEREIRA, Caio Mário da Silva. Instituições de Direilo Civil. 13. ed. Rio de Janeiro: Forense, 2001. v. 6

PITÃO, José António de França. A Posição do Cônjuge Sobrevivo no actuul Direito Sucessório Português. 3. ed. Coimbra: Almedina, 1994.

RODRIGUES, Silvio. Direito Civil: direito das sucessões. 22. ed. São Paulo: Saraiva, 1998.

TEPEDINO, Gustavo. A Parte Geral do Novo Código Civil: estudos na perspectiva civilconstitucional. Rio de Janeiro: Renovar, 2002.

VENOSA, Silvio de Salvo. Direito Civil: direito das sucessões. São Paulo: Atlas, 2001. 